\title{
Sufi Teolojinin Peygamberlik Algısı
}

\author{
MAHMUT AY \\ DOÇ. DR., ANKARA Ü. İLAHIYAT FAKÜLTESI \\ e-posta: may@divinity.ankara.edu.tr
}

\begin{abstract}
The Perception of Prophecy in Sufi Theology. This article deals with the thematic qualities of sufi theology on prophet and prophecy. The prophecy of sufi paradigm is founded upon the concepts of inspiration, Saint(waliy) and karamah. Alternatively the prophecy of intellectual theology(i.e. that of Islamic philosophy and kalam) and textual theology(i.e. that of salaf) is founded upon the concepts of revelation, prophet/apostle and miracle. The prophet and prophecy in sufi theology have a historical dimension and a non-historical dimension at the same time. Its non-historical dimension is considered more important than Its historical dimension. The concepts of revelation, prophet/apostle and miracle forming the imagination of prophecy in intellectual and textual theologies transforms into inspiration, Saint(waliy) and karamah in sufi theology. Thus, it may be concluded that the perception of prophecy in sufi theology is possibly formulated as alternative to that of intellectual end textual theologies prophecy.
\end{abstract}

\section{key words}

sufi theology, prophet, prophecy, inspiration, Saint(waliy), karamah, revelation, miracle.

\section{Giriş}

İslam düşüncesini oluşturan teolojik paradigmaları ${ }^{1}$ kelami, felsefi, selefi ve sufi olmak üzere kabaca dörde ayırmak mümkündür. Bu paradigmaların

1 Metin içerisinde yer verilen "teolojik paradigma" ifadesi ile İslam düşüncesini oluşturan, kendine özgü epistemolojik içerikleri olan, yazılı ve yazılı olmayan kurallar ve uygulamalar bütününe sahip, kuramsal ve düşünsel modeller kastedilmektedir. Felsefe, kelam, selef ve tasavvuf şeklinde literatüre girmiş olan bu modellerin her birinin kendine özgü bir düşünüş, anlayış ve kavrayış biçimi vardır. Her bir model ya da paradigma Tanrı, insan, evren, peygamberlik ve ahiret gibi konularda kendine özgü teolojik bir yaklaşım sergilemiştir. Başka bir ifadeyle her bir paradigma diğeriyle ilişkili olmakla birlikte diğerinden farklı özellikler taşır. Aslında Teoloji kavramı kendine özgü yöntem ve içeriği olan kendi başına, bağımsız bir disiplini ifade eder. 
her birinin, herhangi bir teolojik konu hakkında, kendine özgü yaklaşımları ve kavram dünyaları söz konusudur. Kelami ve felsefi teolojiyi akıl kavramıyla, selefi teolojiyi metin kavramıla ve sufi teolojiyi de kalp kavramı ile karşılamak olanaklıdır. Başka bir deyişle felsefi teolojinin, sorunları akla, kelami teolojinin akla ve vahye ${ }^{2}$ selefi teolojinin metne, sufi teolojinin ise kalbe dayalı olarak kurguladığını söyleyebiliriz. Buradan hareketle kelami ve felsefi teolojiyi anlama ve kavrama faaliyeti(acts of intellect), sufi teolojiyi ise zevk alma faaliyeti(acts of tasting) olarak görmek gerekir. Bir zevk ya da halden hale girme yolu olarak da ifade edilebilecek olan sufi teoloji, akıl yürütme, düşünme, anlama ve kavrama kaygısı taşımaz. Dini tecrübenin bir türü olarak kabul edilen sufi tecrübe aslında insan doğasının sahip olduğu eğilimlerden birini ifade eder. Bu tecrübe diskursif yolla ya da teorik olarak değil, ancak yaşanarak öğrenilebilen bir tecrübedir. Aklın kavradığı değil, nefsin yaptığı organik bir hayat vetiresidir. Spiritüel bir aktivite olan bu tecrübenin amacı transandantaldır. ${ }^{3}$ Pek çok sufi teorisyen, ilahi olanın cazibesine kapılıp sonsuza doğru sürüklenip gitme halinin kelimelerle anlatılamayacağını ancak yaşanabileceğini ifade ederler. Sufinin yaşadığı halleri kısaca anlatan, başka bir ifadeyle sufi teolojiyi özetleyen "tatmayan bilmez" önermesi ${ }^{4}$, kelime ve kavramların bu tecrübeyi anlatmada yetersiz kalacağını ifade eder.

Teolojinin temel tartışma alanlarından biri olan peygamberlik konusunda kelami teolojinin selefi teolojiye, felsefi teolojinin de sufi teolojiye yakın bir tutum benimsediğini söylemek yanlış olmaz. Başka bir deyişle kela-

Ancak söz konusu paradigmaların Tanrı, İnsan, evren, peygamberlik ve ahiret gibi konular hakkında belirli epistemolojik ve ontolojik içerik taşıdıkları dikkate alındığında, her bir paradigmanın kendine özgü bir teolojisinin olduğunu söylemek mümkündür. Örneğin metinde geçen sufi teolojisi, tasavvufi geleneğin Tanrı, insan, tabiat, peygamberlik, ahiret gibi konulardan oluşan düşünsel ve kuramsal çerçevesini ifade eder. Buradan hareketle İslam düşüncesi içerisinde birden fazla teolojiden söz etmek mümkündür.

2 Felsefi ve kelami teolojilerin aklı kullanırken hareket noktaları ve kaygıları birbirinden farklıdır. Filozoflar, felsefi geleneği temellendirme ve savunma adına aklı kullanırken, kelamcılar vahyi temellendirmek ve savunmak adına aklı kullanmaktadırlar. Zira kelam, vahyi göz ardı ederek yürütülen bir faaliyet değildir. Kelam ilmi, İslam'ın inanç esaslarını Kur'an'dan çıkararak, bunları akıl yoluyla temellendirmeyi esas edinir.

3 Sunar, Cavit, Tasavvuf Tarihi, Ankara, 1975, s.6-7 vd.; Mistisizmin Ana Hatları, Ankara, 1966, s.4-10; Ertürk, Ramazan, Sufi Tecrübenin Epistemolojisi, Ankara, 2004, s.75-76.

4 Arapça'da, "men lem yezuk lem ya'rif" şeklinde formüle edilen bu tecrübenin teori ile değil pratik ile ilgili bir durum olduğu pek çok sufi otorite tarafindan dile getirilmektedir. Sufi tecrübede nihai amacın öğrenmekle değil, tatmak, yaşamak ve halden hale girmek suretiyle gerçekleşebileceğini ifade eden Gazali, söz konusu tecrübenin teorisinin hiçbir zaman pratiğini anlatmaya yetmeyeceğini vurgulamaktadır. Gazali'ye göre bunun en güzel örneği sarhoşluğun tanımı ile sarhoş olmak ya da hastalığın tanııı ile hasta olmak arasındaki farktır. Bkz. Gazali, el-Munkız mine'd-Dalal, çev. Hilmi Güngör, İstanbul, 1990, s.56. 
mi teolojinin peygamberlik tasavvuru metin teolojisiyle paralellik taşırken, felsefi teolojinin peygamberlik anlayışı da sufi teolojinin peygamberlik anlayışıyla paralellik taşımaktadır. Bu çalışma, paradigmalar arası karşılaşıırmaya yönelik olmadığından bu genel değerlendirme ile yetinmek istiyoruz.

Bu çalışmada, sufi paradigmanın peygamberlik algısının irdelenmesi ve bu algının Kur'an perspektifinden değerinin belirlenmesi öngörülmektedir. Teolojik sistemlerin peygamber algısı ve peygamberlik anlayışı, onların Tanrıinsan ilişkisini nasıl kurguladıklarıyla doğrudan ilgilidir. Kelam ve felsefenin aksine sufi paradigma pratik yaşama ilişkin olup, Tanrı-insan ilişkisinde kalp kavramını ön planda tutar. Tanrı-insan ilişkisinde kelami paradigma Tanrı merkezli yukarıdan aşağıya doğru bir iletişim ve ilişkiyi benimserken, sufi paradigma insan merkezli aşağıdan yukarıya pratik bir ilişkiyi öngörür. Akıl ve metin teolojisi bu ilişkide Tanrı'nın varlı̆̆ı ile insanın varlığını kesin olarak birbirinden ayırmayı ve tenzihe dayalı bir yaklaşımı benimserken, kalp teolojisi Tanrı ile insanın birleşmesini ilke edinir. Bu durum varlıkta birlik teorisine karşlık gelir.

Tanrı-insan ilişkisinin kaynaklık ettiği kelami-felsefi varoluşsal ve bilişsel birikimde varlık kavramı merkezi bir yer işgal eder. Öyle ki bu düşünce sistemlerinde yokluk kavramına bile bir tür varlık atfedilir. ${ }^{5}$ Bunun aksine kalp teolojisinin ontolojisi ve epistemolojisi yokluk ya da fena kavramı üzerine kuruludur. Örneğin insan gerçek varlı̆̆ını yoklukta ya da fenada bulur. Başka bir ifadeyle insan benliğini ancak yok ederek ya da kapsamlı bir birlik içerisinde eriterek gerçekleştirebilir. Bunun en iyi örneği sufinin yaşadığ1 içsel hallerin teorileşmiş formu olan vahdet-i vücud'tur. ${ }^{6}$

Sufi geleneğin Tanrı-insan ilişkisini özetleyen ve peygamberlik anlayış1na da temel oluşturan insan-1 kamil teorisi ${ }^{7}$, Hz. Muhammed'e atfedilen ve

5 Filozofların ve kelamcıların yokluk hakkındaki değerlendirmeleri için bkz. Ay, Mahmut, Sadruşseria'da Varlık, Ankara, 2006, s.150-178.

6 Vahdet-i Vücud, gerçek anlamda sadece Tanrı'nın var olduğunu, bütün varolanların O'nun ad ve niteliklerinin tecellileri olduğunu, görünüşteki çokluğun ardında tek bir varlığın bulunduğunu, varlıkta birliği savunan felsefi ve tasavvufi anlayıştır. Özellikle İbn Arabi tarafından bir felsefi ve metafiziksel teori şeklinde sistematize edilen bu anlayış nihai anlamda, İslam'ın Allah'ı ile tasavvufun metafiziksel Hakikat'ını, yine İslam'ın yalın tevhid öğretisi ile tasavvufun felsefi ve metafiziksel içerikli varlıkta birlik öğretisini, başka bir ifadeyle İslam'ın "Allah'tan başka ilah yoktur" önermesi ile tasavvufun "Allah'tan başka hiçbir şey yoktur" önermesini uyumlu hale getirmeyi amaçlar.

7 Tasavvufi literatürde ilk defa Hüseyin İbn Mansur el-Hallac tarafından dillendirilen ve büyük olasıllkla çevre inanç ve kültürlerin hulul(incarnation) inancından transfer edilen bu teori, özellikle İbn Arabi ve Abdulkerim Cili gibi sufi önderler tarafından kapsamı genişletilerek sistematize edilmiştir. Hallac, insanın İlahi(el-lahut) ve beşeri(en-nasut) olmak üzere iki do- 
tamamıla akıl ve metin teolojilerinin Tanrı-insan ilişkisine aykırı olan, "Allah, Adem'i kendi suretinde yarattı" ${ }^{8}$ rivayetine dayanır. Sahip olduğu sıfatlarla tüm var olanlara tecelli eden Allah, en üst düzeyde, insan-1 kamil anlamında peygamberler ve velilerin şahsında temsil edilir. Sufi gelenekte her bir peygamber ve veli birer insan-1 kamil modelidir. Bu modelde, insan İlahi kudretin faaliyetini gerçekleştirdiği bir mahalle dönüşmektedir.

Sufi teolojide insan-1 kamil Tanrı'nın yeryüzündeki ve varoluş alemindeki halifesi olarak kabul edilmektedir. Onun Allah'ın halifesi oluşu, kendisindeki cem etme $e^{9}$ yeteneğinden ileri gelmektedir. Bu yetenek varlıklar içerisinde sadece insan-1 kamile verilmiştir. Zira Tanrı, insan-1 kamil'in görünen yönünü alemin hakikatlerinden batıni yönünü de kendi suretinden inşa etmiştir. Bu şekilde inşa edilmek onu diğer varlıklardan ayırmakta ve ayrıcalıklı kılmaktadır. Onun halifeliği sırf bu yeteneğine dayanmaktadır. Bütün varlık alemi Allah'ın hazinesi olarak değerlendirildiğinde, insan da

ğasının var olduğunu, bunların birleşmediğini ancak şarabın suda dağıldı $\breve{g} ı$ gibi birinin diğeri içerisinde dağıldığını savunur. Müslüman geleneğinde ilerleyen zamanlarda insanın ilahi yönü ya da insanın ilahlık rolü şeklinde nitelendirilebilecek zihniyet ve inanç sorununa dönüşecek olan bu görüş İbn Arabi başta olmak üzere önde gelen sufi otoritelerce benimsenerek metafiziksel bir insan teorisine dönüştürülmüştür. Bu metafiziksel insan teorisine göre lahut ile nasut yani ilahi ile beşeri olan birbirinden bağımsız iki tabiatı değil, tek bir hakikatin iki görünümünü ifade eder. Bu iki görünüm varlık olarak sadece insan için değil, varolan her şey için geçerlidir. Aslında bir bütün olarak alem, Allah'ın isim ve sıfatlarının çeşitli şekillerde tecelli ettiği bir yerdir. Ancak insan, bu sıfat ve isimleri külli bir şekilde tecelli ettirir. Yani nasut ve lahutun mükemmel bir tarzda tezahür ettiği varlık insandır. Burada nasut, herhangi bir şeyin zahiri yönüne, lahut ise batıni yönüne işaret etmektedir. Bü yüzden tüm gerçeklikleri ve varlık tabakalarını kendisinde topladı̆̆ından dolayı insana, el-muhtasaru'ş-şerif, el-kevnu'l-cami adı verilir. Allah'ın varlığı en mükemmel tarzda sadece insanda yansır. Allah kendi bilincini ve kemalini mikrokozmos olan insanda bulur. Ancak bu şerefli makam her insan için geçerli değildir. Allah'ın tecellisi, özellikle peygamber ve velilerde en üst düzeyde temsil edilmektedir. Bkz. İbn Arabi, Fususu'l-Hikem, Thk. Ebu'l-Ala Afifi, Beyrut, 1980, s.55-56, 101-105, 110-114, 122-123; el-Cilani, el-İnsanu'l-Kamil fi Marifeti'l-Evahir ve'l-Evail, Mısır, 1316, II/s.46-50; Afifi, A. E., "İbn Arabi", İslam Düşüncesi Tarihi içerisinde, İstanbul, 1990, II/s.28-29.

8 Bkz. Buhari, İsti'zan, 1, Enbiya, 1; Müslim, Cennet, 28; Ahmet b. Hanbel, Müsned, II/315.; Sufi teolojinin Peygambere atfen kullandığı bu rivayet, Yahudilikte yaratıllş kapsamında, "Ve Allah dedi: Suretimizde, benzeyişimize göre insan yapalım.... Ve Allah insanı kendi suretinde yarattı." şeklindeki ifadelerle dile getirilmektedir. Bkz. Tekvin, 1: 26-27.

9 Sufinin yaşadığı makam ve hallerden biri olan cem, Tanrı dıșındaki bütün varlıklarla ilgili hislerin yitirilmesi anlamına gelir. Bu aşamada sufi, Tanrı tarafından, bir çarpılma ve beşeri düzlemden koparılma hali ile evrendeki varlıkları görmekten alıkonulur. Bu noktada o, kendi varlığı başta olmak üzere Tanrı dışındaki bütün varlıklar hakkındaki bilincini ve duyarlılığını kaybederek, sadece Tanrı'dan gelen ve kendisini istila eden tecellilere boyun eğer. Bundan böyle sufi her yönüyle Tanrı tarafından yönetilmektedir. Eylemleri Tanrı tarafından yönlendirilmektedir. Bu hali yaşayan sufi ise, bütün olup bitenlerin farkındadır. İşte bu farkındalık sufi literatürde cem etme yeteneği olarak adlandırılmaktadır. Bkz. Kuşeyri, Kuşeyri Risalesi, haz. Süleyman Uludă̆, İstanbul, 1991, s.192-195.; Kelabazi, Taaruf-Doğuş Devrinde Tasavvuf, haz. Süleyman Uludağ, İstanbul, 1992, s.177-180. 
bu hazineyi korumak üzere tayin edilen muhafız ve vekil olmaktadır. ${ }^{10}$ İnsan bu vekaleti, varlık aleminde Tanrı'nın bütün isim ve sıfatlarının tecelli ettiği tek varlık olmasına borçludur. Sufi teolojide insanın halifeliğgi ona özgü bir ezelilik doğurmaktadır. Tanrı ezeli olduğu gibi insan da ezelidir. Tanrı'nın ezeliliği açık, insanınki gizlidir. Tanrı özü ya da zatı gereği ezeli, insan ise varlığının belirli bir yönü gereği ezelidir. İnsan, ezeli bilgide bulunması açısından ezeli olarak mevcuttur. İnsan, tıpkı cevherde bulunmak nedeniyle arazın mekana yerleşmesi gibi, kendisine ilişen ilahi bilginin inayetiyle var olmuştur. ${ }^{11}$

Müslüman düşünceyi oluşturan her paradigmanın özgünlük açısından meşruiyetini Kur'an'a ve Peygamberin uygulamalarına dayandırması gelenek halini almıştır. Böyle olmakla birlikte her paradigmada kavramsal ya da düşünce düzeyinde bir diş etkiden söz edilebilir. Müslüman kültüründe ortaya çıkan asketik ve mistik tecrübenin bu yabancı etkiye en fazla maruz kalan alan olduğu söylenebilir. ${ }^{12}$ Hatta insan ruhunun Tanrı'ya kavuşma ve Onunla birleşme adına duyduğu sürekli arzunun dinsel olsun ya da olmasın hemen her kültür ve inanç sisteminde evrensel bir fenomen olarak ${ }^{13}$ karşımıza çıktığı bir gerçektir. Bu fenomen, en geniş anlamıyla, Hikmet, Işık, Aşk ve Yokluk şeklinde adlandırılan Tek Hakikatin bilincine varmak biçiminde tanımlanabilir. ${ }^{14}$ Mistisizm olarak adlandırılan bu fenomen, dinsel olmaktan çok felsefi bir içerik taşır. Hangi inanç ve kültür sistemi içeri-

10 İbn Arabi'ye göre halife, ortaya çıkışı daha sonra gerçekleşmiş olan ezeli insandır. O, ebedi olan sürekli bir yenileniştir. Aynı zamanda o, bütün yönleriyle görüneni ve görünmeyeni şahsında toplayan Kelime(logos)'dir. Bu yüzden alem, onun varlık alanına çıkmasıyla tamama ermiştir. Onun alemle olan ilgisi yüzüğün taşı ile olan ilişkisi gibidir. İnsan-1 kamil bu özelliğiyle Padişah(Tanrı)'ın hazinesini mühürlerken kullandığı mührünün yazı ve işaretlerinin mekanıdır. Mührün Padişahın hazinelerini koruması gibi halife de Padişahın halkını(varlıkları) korur. Allah alemin korunması konusunda insanı vekil kılmıştır. Buna göre insan-1 kamil var olduğu sürece alem de korunmuş olacaktır. Bkz. İbn Arabi, Fususu'l-Hikem, thk. Ebu'l-Ala Afifi, Beyrut, 1980, s.49-50.

11 İbn Arabi, Futuhat-ı Mekkiyye, çev. Ekrem Demirli, İstanbul, 2006, I/s.143.

12 Nicholson, Reynold A., The Idea of Personalıty In Sufism, Lahore-Pakistan, 1998, s.8 vd.

13 İnsan doğasının sahip olduğu doğal eğilimlerden biri olarak sufiliğin ya da mistisizmin evrensel niteliğini, sufi teorisyenlerin kendi şiirsel ifadelerinde bulmak mümkündür. Bu evrensel fenomen ya da tecrübe, İbn Arabi'nin Tercümanu'l-Eşvak adlı eserinde şu şekilde dile getirilmektedir:

"Benim kalbim her sureti kabul etmiştir.

Dervişlerin manastır, Hıristiyanların kilisesi olmuştur.

Putperestlerin ibadethanesi, hacilartn kebesidir.

Tevrat sayfaları, Kur'an mushafidir.

Ben sevgi yolunu takip ediyorum.

İşte bu, benim dinim ve imanımdır." Bkz. İbn Arabi, Tercümanu'l-Eşvak, Beyrut, 1961/ 1381, s.42-43.

14 Schimmel, Annemarie, İslamın Mistik Boyutları, çev. Ergun Kocabıyık, İstanbul, 2001, s.20. 
sinde çıkarsa çıksın, temel ilkeleri dikkate alındığında, bu fenomeni, evrensel bir felsefi öğreti olarak yorumlamak gerekir. Nitekim bu öğretiye, bütün dinlerin içinden akan büyük manevi nehir ${ }^{15}$ olarak bakılmıştır. Şu halde pek çok araştırmacının, bu evrensel fenomenin Müslüman kültürü içerisinde doğan ve gelişen, böylece imgesel anlamda İslam'ın rengine bürünen versiyonu için "İslam mistisizmi" ya da "İslam Gizemciliği" ifadesini kullanması büyük oranda doğru bir adlandırmadır.

Sufi teorisyenlerin, sufi dünya görüşünün ve düşünce sisteminin köklerinin Kur'an'a ve özellikle peygamberin uygulamalarına da dayandırmışlardır. Aslında Müslüman kültüründe ortaya çıkan her türlü inanç ve düşünce akımı, her ne zaman özgünlük ve meşruiyet tartışması gündeme gelse, belki de Kur'an'dan daha çok peygamberin otoritesine referansta bulunmuştur. Sufi literatürün peygamberin esoterik(batıni) öğretisi olduğu yönündeki iddiayı destekleme adına, çok sayıda uydurma hadis kullanma ve bu otoriteye gelişigüzel referansta bulunma tasavvufta yaygın bir alışkanlık olarak görülmektedir. Bunun da ötesinde sufi gelenek, tasavvufi doktrinin ve pratiğin İslam'a uygunluğu konusunda kuşku duyanların eleştirilerine maruz kaldığında, hadislerin otoritesine sığındığı bilinmektedir. Bu durum, sufilerin, hadis alanında zayıf olmakla suçlanmalarına neden olmuştur. ${ }^{16}$ Sufi literatürü oluşturan çoğu terim ve kavramın, Kur'an'dan transferi söz konusu olsa da, bağlam ve içerik yönünden tamamen farklı durum arz eder. Kur'an'da dini ve ahlaki bağlam ve içerikte kullanılan bazı kavramlar, tasavvufta makam, derece ve hal teorilerinin üzerine kurulduğu yapıtaşlarına dönüşmüştür. Kalp teolojisinin peygamberlik algisinda ilham, keramet ve veli kavramları kurucu rol oynamaktadır. Bu kavramlar, akıl ve metin teolojilerinde vahiy, mucize ve nebi'ye karşıllk gelmektedir. Bu kavramların sufi teorisyenlerce nasıl kurgulandığını ve onlara hangi anlamların yüklendiğini tespit etmek, peygamberlik algısını belirlemek açısından önem taşımaktadır.

\section{Vahiy-ilham}

Vahiy, Allah kelamının peygamberlere bildirilme ya da iletilme yolu olması bakımından hem Kur'an'ın peygamberlik tasarımının hem de akla ve met-

15 Schimmel, İslamın Mistik Boyutları, s.20.

16 Sufiler tarafından Hz. Muhammed'le ilişkilendirilen sözler ve anekdotlar incelendiğinde bunların sahih olarak kabul edilen hadis kaynaklarının kriterlerine ve ilmi standartlara uymadığı ya da kuşkulu olduğu görülür. Hadis rivayeti konusunda yeterince titiz davranmayan sufilerin hadisleri sahih olup olmadıklarına bakılmaksızın özellikle sufi paradigmayı ve buna dair kurguları destekleme, halkı uyarma, ögüt verme adına kullandıkları gözlemlenebilir. Sufi teorisyenlerin hadis rivayeti konusundaki yaklaşımları için bkz. el-Mekki, Ebu Talib, Kut'u'l-Kulub, Misır, 1310, I/s.176-178. 
ne dayalı teolojilerin kurucu kavramlarından biridir. Tanrı kaynaklı dinlerin temelini oluşturan vahiy, İslam'da merkezi bir yer işgal eder. Vahyin mahiyetinin bilinemezliği bir yana, kaynağının beşeri düzlemin ötesinde Başka bir varlık(Allah) olduğu görüşü, Kur'an'a referansla, İslam düşüncesini oluşturan akla ve metne dayalı teolojide sarsılmaz bir inanç olarak durmaktadır. Aslında Hz. Muhammed'in kendisi de vahyi, kendi dışında Başka bir varlıktan, yani Allah'tan aldığı konusunda en ufak bir şüphe içerisinde olmamıştır. Nitekim O, bu sarsılmaz inancın bir sonucu olarak, Yahudi ve Hıristiyanların Hz. İbrahim ve diğer peygamberler hakkında ileri sürdükleri tarihi iddiaları reddetmiştir. ${ }^{17}$ Vahyin dış kaynaklılığı, objektifliği ve anlam dolu sözlü olma niteliği bizzat Kur'an tarafindan ifade edilmektedir. İslam akaidinin oluşumunda vahyin bu nitelikleri özellikle korunmaya ve bu hususta azami bir hassasiyet gösterilmeye çalışılmıştır. Akidenin oluşumunda vahyin söz konusu nitelikleri hakkında duyulan bu hassasiyet ve özen, dönemin ve coğrafyanın tarihsel ve kültürel koşullarıyla yakından ilgilidir. Gnostik ve irfani kültür başta olmak üzere, Hıristiyan ve Yahudi vahiy anlayışının egemen olduğu tarihsel dönem ve coğrafya, kelamcıların bu hassasiyetini anlamlı kılmaktadır. Kur'an'da ilahi bildirinin ya da iletinin karşılığ olan vahiy kavramının, dönemin söz konusu kültürlerinin temelini oluşturan ilham kavramıyla ilişkilendirilmesi olasılığı bu hassasiyetin yerindeliğgini gösterir.

Çeşitli kültürlerde, akıl, haber, duyular ya da deney dışında, kişilerin kalbine ya da zihnine doğan, kesinliği olmayan, Tanrı'dan geldiği varsay1lan öznel bilgiyi ifade eden ilham, kalbe doğan ani bir tinsel etki olarak düşünülür. Sufi gelenekte ilham, vahiy sonrası dönemde vahyin işlevini gören irşad ve yol göstericiliğin dayanağı olan nebevi bir kalbi eylem olarak görülür. Aslında Tanrı ile insan arasındaki ayırımı ve bu iki varlığın birbirinden farklılı̆̆ını ortadan kaldırmayı, başka bir ifadeyle bu iki varlığın nihayette bir birlik ve bütünlük oluşturduğunu ilke edinen mistik ve gnostik eğilimli felsefi ve dini öğretilerde vahiy olgusuna yer verilmez. Zira bu tür eğilimler taşıyan felsefi ve dini öğretilerde Tanrı insanlara mesajını cisimleşerek verdiği için geriye sadece bu öğretilere inananları doğru yaşamaya sevk eden ilham bilgisi kalır. ${ }^{18}$ Vahiy merkezli dinlerin egemen olduğu kültürel yapı içerisinde ortaya çıkan mistik tecrübelerde ise vahiy, metin ve akıl kaynaklı formunu yitirerek, anlam ve içerik dönüşümüne uğrar. Bu durumda vahiy bilgi türü olma bakımından ilhamla

17 Fazlurrahman, İslam, çev. Mehmet Dağ-Mehmet Aydın, İstanbul, 1981, s.36.

18 Sinanoğlu, Mustafa, "ỉlham”, İslam Ansiklopedisi(TDV), İstanbul, 2000, XXII/100. 
özdeş olup, aralarında sadece derece ve değer bakımından bir fark söz konusudur. ${ }^{19}$

Sufi gelenekte vahiy, dış kaynaklılık, objektiflik ve sözlü olma gibi niteliklerini kaybederek sadece insan ruhunun bütün tinsel güçlerinin toplandığ 1 ve aktif hale geldiği bir faaliyete dönüşür. Bu gelenekte vahiy, ne bir dış kaynağa bağlı olma ne de sözlü olma niteliği taşır. İnsan benliğinde potansiyel olarak bulunan bir gizil gücün yansımasından ibaret olan vahiy/ilham, tamamen insan doğasında ortaya çıan kalbi bir eylemdir. İbn Arabi vahyin doğa üstü bir kaynağının, yani ilahi bir vahyedici ve beşeri bir alıcı şeklindeki formülasyonun olmadığını, onun tamamen insan doğasına ait olduğunu düşünür. Ona göre vahye muhatap olan bir kimse, kendisine sahip olmadığı bilgileri bağışlayan bir varlık müşahade edecek olsa, bu varlık, onun kendi özünden başkası değildir. Aslında bu kimse, ayna önünde duran bir kimsenin kendi suretini görmesi gibi, kendi benlik ağacının, yani kendi bilgisinin meyvesini toplar. ${ }^{20}$

Sufi teorisyenlerin vahyi reddetmek yerine, ona sezgisel bir içerik ve anlam yüklemelerinin temelinde meşruiyet sorunu yatmaktadır. Özellikle Hallac'in tedbirsiz coşkusunun bedelini hayatıyla ödemesi, sufi teorisyenleri daha dikkatli olmaya ve Sünni çizgiye yakın seyreden ince bir doktrin keşfetmeye sevk etmiştir. Bu bağlamda sufi teorisyenler Hz. İsa'nın yerine Hz. Muhammed'i koyarak, Hallac'in sivri dili yerine daha 1 lımlı bir dil ve üslup benimseyerek kendilerine yönelen eleştirileri ve kuşkuları giderecek bir teorik irfan sistemi icat etmişlerdir. ${ }^{21}$

19 Sufi geleneğin yirminci yüzyıldaki en büyük temsilcisi olarak görülen reformist düşünür Muhammed İkbal, peygamberin vahiy denilen en büyük dini tecrübe ile onurlandırıldığını belirterek, Kur'an'da kullanılan biçimiyle vahyin, hayatın evrensel malı olduğunu düşünmektedir. Ona göre vahiy, bitki, hayvan ve insanların hayatlarında ilham biçiminde aktif olup alıcının ihtiyaçlarına göre biçim ve nitelik değiștirmektedir. Vahyin kaynağı göz önüne alındığında, İslam peygamberinin kendisi eski dünyaya, eski çağlara mensuptur. Ancak vahyin kendisi öz itibariyle yeni dünyaya, yeni çağlara mensuptur. İkbal peygamberliğin Hz. Muhammed'le son bulmasını bu anlamda değerlendirmektedir. İkbal, bir peygamberin mistik ve dini tecrübesinin sona ermediğini vahyin biçimsel ve niteliksel dönüşümü ile ifade etmektedir. Bkz. İkbal, Muhammed, İslam'da Dini Tefekkürün Yeniden Teşekkülü, çev. Sofi Huri, İstanbul, 1999, s.143144.; Kayani, Muhammed Han, Felsefe, Siyaset ve Şiir Dünyastyla İkbal, İz Yay., İstanbul, 2002, s.62-63.

20 İbn Arabi, Fusus, 66-67.; İbn Arabi, başta Fusus olmak üzere kitaplarının bir çoğunun vahiy/ ilham ürünü olduğunu, kitaplarında yazdı̆̆ her şeyin akıl yürütme ve düşünme sonucunda değil, kalbindeki vahiy meleğinin üflemesiyle meydana geldiğini, her şeyin ilahi ruhtan kendi ruhuna üflenmesiyle yazdırıldığını ileri sürmektedir. Bkz. İbn Arabi, Fusus, 47.; Futuhat, I/ s.36, 125-137.; Afifi, "İbn Arabi", II/s.17.

21 Arberry, A. J., Tasavvuf-Müslüman Mistiklere Toplu Bakış, çev. İbrahim Kapaklıkaya, İstanbul, 2004, s.89. 
Kur'an açısından vahiy, varoluşsal düzlemde Tanrı ile insan arasındaki ayırımın temelini oluştururken, ilham, Tanrı ile insan arasındaki mesafenin kalkmasını ve her iki varlığın birleşmesini ifade eder. Sufi teoloji gerçekte insanın bu dünyadaki durumunu bir düşüş olarak yorumlar. Sufi tecrübenin yegane amacı insanı cismani yaratılıştan önceki sonsuz ilahi hakikatine kavuşturmaktır. Zira insan sonsuzluk aleminden doğal olmayan kötülüklerle dolu geçici aleme atılmış durumdadır. Bundan kurtulmanın yolu ilhama mazhar olacak düzeyi yakalamak için çaba göstermektir. Bu çaba güçlü bir arzu ve iştiyak gerektirir.

Sufi kendisini hapseden beden gömleğinden ve onu bu aleme bağlayan her şeyden keşf ve ilham vasıtasıyla sıyrılabilir. Ayrıldığı ilahi hakikate dönüş için, her şeyden önce nefsin birliğinin yeniden sağlanması içine düştüğü dünya hapishanesinden kurtulmasına bağlıdır. Bunun için yapılması gereken ilk şey, zatın birleştirilmesidir. Bu da ruhsal varlığın yeniden düzenlenmesini gerekli kılar. Sufinin atması gereken ilk adım, kendini tanımasıdır. İnsanın nefsini tanıması, doğduğu hakikati, yani ilahi ve sonsuz özü aramaya başlamasıyla mümkündür. Bu arayışta söz konusu öze yönelik bilgi ve bilinç arttıkça, ona doğru iştiyak, yükseliş ve yakınlaşma gerçekleşir. Bu yakınlaşma, ilahi özle karşı karşıya gelecek bir düzeye kadar(kab1 kavseyn) ulaşır. İşte bu aşamadan sonra aşıkın maşukla birleşmesi yaşanır. ${ }^{22}$ Buna sufi literatürde fena adı verilir. Böylece sufi ilham yoluyla asl1na rücu etmiş, bütün dünyevi bağlarından sıyrılmış, ilahi özle donanmıştır. Sufi teolojide bu sonuca akıl ve nalsa ulaşılması mümkün değildir. Ancak ilham ve keşf insanı bu ilahi hakikate ulaştırabilir.

Sufi teorisyenler, kalbe ve iradeye dayalı paradigma ile İslam düşüncesini oluşturan akla ve metne dayalı diğer paradigmalar arasında baştan beri bir ayırım öngörmüşlerdir. Bu genel ayırım, özelde varoluşsal ve bilişsel alanda da geçerlidir. Bu ayırım eşit düzeydeki bir farklılığı değil, ilahi lütuftan kaynaklanan bir üstünlügü ifade eder. Sufi teolojide keşif ya da ilham yoluyla elde edilen bilgi, vahiy, duyular ve akıl yoluyla elde edilen bilgiden daha üstündür. Önde gelen sufi önderlerden biri olan Zünnun el-Mısri(ö. 245/859) keşif, müşahade ve ilham yoluyla elde edilen bilgiyi yani marifeti duyular ve akıl yürütme sonucu elde edilen bilgiden yani ilimden kesin olarak ayırmakta ve bu bilgi türüne, Tanrı'nın bir inayeti olması ve O'nun sevgisinden kaynaklanması nedeniyle bir üstünlük tanımaktadır. ${ }^{23}$ Büyük

22 Cabiri, M. Abid, Arap-İslam Kültürünün Akıl Yapısı, İstanbul, 1999, s.336-337.

23 Sufi literatürün oluşmasında büyük rol oynayan Zünun'a göre üç türlü bilgi vardır. Bunlardan birincisi Allah’ın birliğinin bilgisi olup, bütün inananlar için ortak bir husustur. İkincisi, akli 
sufi önderlerden Cüneyd-i Bağdadi bilgiyi tanınma(taaruf) ve tanıtma(tarif) şeklinde ikili bir ayırıma tabi tutar. Ona göre tanınma, Tanrı'nın dolayısız olarak kendisini insanlara bizzat tanıtmasıdır. Tanıtma ise, akıl aracıl1ğıyla Tanrı'nın insanlara kudretinin eserlerini göstermesidir. Bu iki tür bilgiden birincisi seçkinlere, ikincisi ise sıradan halka ait bilgidir. ${ }^{24}$

Sufi teorisyenler akla, duyulara ve nassa dayalı bilgiler aracılığıyla Tanrı'yı tanımanın ve hakikatlere ulaşmanın mümkün olmadığını düşünürler. Zira söz konusu yollarla elde edilen bilgiler yaşanan ve duyumsanan dünyayla sinırlıdır. Oysa marifet adı verilen ve keşf ve ilham yoluyla elde edilen bilgiler akıl ve duyu ötesi alana özgüdür. Tanrı akıl ve duyu ötesi bir varlık olduğundan, Onu ne akıl ve düşünce ile ne de vahiy ile gerçek anlamda tanımak mümkündür. Bu yüzden Kelami ve felsefi teolojinin Tanrı hakkında geliştirdikleri akli ve nakli delillerin hiçbir anlamı yoktur. Tanrı'yı tanımanın yegane yolu Tanrı'nın kendisidir. Bu da Tanrı'nın kendisini arife açmasıdır.

Varoluşsal ve bilişsel düzlemde sufi paradigmanın diğerlerinden ayrı ve üstün olduğuna yönelik benzer ifadeler kayınpederi Ebu Ali ed-Dekkak'tan nakille Kuşeyri(ö.465/1072) tarafından dile getirilmektedir. Ona göre diğer insanların çabalayıp elde etmeye çalıştıkları bilgiler Allah tarafından velilere verilmiştir. İnsanların çabalayıp ulaşamadıkları bilgiler velilere malum olmaktadır. Bu yönüyle veliler, hem nakil ve rivayete dayanan selef teologlarından hem de akla ve düşünceye dayanan kelamcı ve filozoflardan daha üstündür. ${ }^{25}$ İbn Arabi bilgiyi akıl, hal ve sır ilmi şeklinde üçlü bir ayırıma tabi tutarak, keşf ve ilham yoluyla elde edilen sır ilmine ve bu ilmin temsilcilerine değer yönünden üstünlük tanımaktadır. ${ }^{26}$ Sufi teorisyenler Tanrı'ya çıkılan yolculukta önce imanın, sonra bilginin ve daha sonra da zevkin tecrübe edilmesi gerektiğinin belirtirler. ${ }^{27}$ Aslında bir bütün

kanıtlarla ve çıkarımlarla elde edilen bilgi olup filozofların, hatip ve kelamcıların sahip olduğu bilgidir. Üçüncüsü ise Allah'ı kalpleriyle müşahade eden velilerin sahip olduğu birliğin sıfatlarının bilgisidir. Velilerden başka hiçbir varlığın ulaşamadığı hakikatlerin bilgisi, Allah tarafından sadece velilere gösterilir. Attar, Muhammed b. İbrahim Feriduddin, Tezkiratu'l-Evliya, nşr. Retnold A. Nicholson, London-Brıll, 1905, I/s.127.; Tezkiratu'l-Evliya(Yazma), Konstantiniyye, 1086, Ankara Ünv. İlahiyat Fak. Kütüphanesi, No: 0036011, 276 varak, v.61a.

24 Kelabazi, Taaruf-Doğuş Devrinde Tasavvuf, haz. Süleyman Uludağ, İstanbul, 1992, s.95.

25 Kuşeyri, Kuşeyri Risalesi, s.219-220, 487 vd.

26 İbn Arabi'ye göre düşünmeye ve akıl yürütmeye dayanan akıl ilmi teoriktir. Hal ilmi ise duyular aracılı̆̆ıyla elde edilen bilgileri kapsar. Bunlara göre daha kuşatıcı ve kapsayıcı olan sır ilmi, aklı ve duyuları aşan, akla ve duyulara kapalı olan, peygamber ve velilerin sahip olduğu bilgileri içerir. Marifet adı verilen bu bilgi seçkinlere özgü olup, avama özgü olan akıl ve hal bilgilerinden daha değerlidir. Bkz. İbn Arabi, Futuhat, I/s.74-79, 95.

27 Sühreverdi, Avarifu'l-Maarif, el-Matbaatu'l-Vehbiyye, 1292, I/s.36-37. 
olarak tasavvufi tecrübe iman tecrübesidir. Bu tecrübe, hiçbir şekilde akli muhakeme ve düşünme faaliyeti içermez. Sufi nazarında herhangi bir akletme ve buna dayalı muhakeme girişimi bu tecrübenin büyüsünün ve sıhatinin bozulması anlamına gelir.

Sufi teolojide eğitim ve öğretim yoluyla elde edilen, akli yöntemler kullanılarak ulaşılan istidlali bilgi dünyevi olduğu gerekçesiyle bir değer ifade etmez. Gerçek bilgi, eğitim ve öğretime, nazar ve istidlale konu olmayan bilgidir. Keşf ve ilham yoluyla elde edilen bu bilgi veraset yoluyla intikal eder. $^{28}$ Sufi teorisyenler nazar ve istidlali yolla elde edilen bilgileri ilim, keşf ve müşahade yoluyla ulaşılan bilgiyi de hikmet olarak adlandırmaktadırlar. Hakikat, irfan, kalp, aşk, ledün, batın ve hal bilgisi olarak da adlandırılan hikmetin Allah'ı bilmekten ibaret olduğunu, bu yönüyle her türlü akli, felsefi ve kitabi bilgiden kesin olarak farklı ve üstün olduğunu savunan sufiler, bu bilginin öğrenme ve öğretmeyle elde edilemeyeceğini, kalbe doğrudan aktığını düşünürler. ${ }^{29}$ Keşf ve ilhama dayalı sufi hikmet, dünya hayatını ve avamı dışlayan bir karakter taşır. Sufi tarafından tasarlanan bu kurgusal teori, gizliliğe dayalı olup seçkincidir. Sonsuzluğu talep etme adına çıkılan bu yol, Tanrı tarafından seçilmiş olanlara yöneliktir. Seçilmişlerin kendilerine keşfolunan hakikatleri avama açıklaması doğru değildir. Dolayısıyla bu hakikatleri ancak bu yolun adaylarına ifşa etmeye izin verilir. ${ }^{30}$ İşte bu yönüyle hikmet, dünyaya mesafeli, seçkinci, zaman ve mekan dışı uhrevi bir kurtuluş tasarımıdır.

Akıl ve metne dayalı teolojilerin gereksiz ve faydasız görülerek küçümsenmesine, bunun yerine dolaysız bilginin yani ilhamın tercih edilmesine yönelik düşünceler sufi literatürde önemli bir yer tutmaktadır. Sufi önder-

28 Sühreverdi, Avarif, I/s.23-24.

29 Sufilere göre kitabi bilgi ile sufi hikmet arasında uzlaştırılamaz farklılıklar vardır. Her şeyden önce akli ve istidlali bilgi öğrenme ve öğretmeyle elde edilir. Hikmet ise insanın kendisini aç bırakmasıyla oluşur. Kitabi bilginin kaynağında dil ve buna bağlı mantık vardır. Hikmetin ise aklı ve duyumsanan alanı aşan bir kaynağı vardır. Hikmet gaypten çıkarak kalbe akar. Birincisi görünen alemle ilgili, ikincisi batınla ilgilidir. Görünen alemle ilgili olan zahirin bilgisi dil ve mantıkla ilgilidir. Dil ve mantık ise mülk aleminin(dünya) hazine bekçisidir. Batın ya da aşk bilgisi ise kalp ve gönülle ilgilidir. Gönül, zaman ve mekan üstü melekut aleminin hazine bekçisidir. Akli ve felsefi bilgi kitaplarda yazılı olup sıradan halk içindir. Oysa kalp ilmi olan hikmet, kalplerde gizli olup halka açıklanması doğru değildir. Sufiler, eşyanın görünen boyutu ile ilgili olan ve akıl, vahiy ve duyular yoluyla elde dilen bilgilere ilim, iç yüzünü keşfetmeye yönelik olan ve sadece keşf ve ilham yoluyla elde dilen bilgilere de marifet diyerek, ilmin sıradan halka marifetin ise Tanrı'nın seçkin kulları olan velilere ait olduğunu düşünürler. Bkz. Kelabazi, Taaruf, s.97-98.; Erzurumlu İbrahim Hakk1, Marifetname, sad. Turgut Ulusoy, İstanbul, 1974, I/s.202-203; Ayni, M. Ali, İslam Tasavvuf Tarihi, İstanbul, 1985, s.50 vd.

30 Cabiri, M. Abid, Arap-İslam Kültürünün Akıl Yapısı, s.337. 
ler, bir ölçüde düşüncenin dinamikliğini yansıtan mezheplerin görüş ayr1lıklarına ve soyut düzeyde kalan teorik teolojik tartışmalara karşı hep ilgisiz kalmışlardır. Hucviri'nin, "Bilinmelidir ki ilimler çoktur, insan ömrü k1sadır. Nücum(Astronomi), tıp, matematik, güzel sanatlar ve benzeri ilimlerin hepsinin öğrenilmesi halk için gerekli değildir. Bu ilimlerin sadece şeriatla ilgisi olanların, ilgileri oranında öğrenilmesi gereklidir." ${ }^{11}$ Şeklindeki ifadeleri bilimsel ve teolojik faaliyetlere karşı sufi tutumunu yansitmaktadır. Hucviri bu ifadeleri ile namazda yön tayin edebilecek kadar astronomi, zekat miktarını hesaplayacak kadar matematik bilmenin Müslüman birey için yeterli olacağını düşünmektedir. Pek çok sufi, akla ve bilme karşı duyulan tepki ve güvensizliğin, Tanrı'ya ulaşma adına çıkılan yolculuğun ilk adımı olarak değerlendirilmiştir. Başka bir ifadeyle Tanrıya yolculuk, aklı ve bilimi yadsımayla başlar. Bu yolculuğa çıkmak için gerekli olan içtenlik, mürekkep hokkalarının kırılmasını ve kitapların yırtılmasını gerektirir. ${ }^{32}$ Dolayısıyla insanı gerçek bilgiye(marifete) ulaştıran kitaplar değil, aşktır.

Öyle anlaşılmaktadır ki sufi teolojide gerçek ve doğru bilgi ancak Tanrı'nın, bilginin saf parlaklılığı ile kalbi aydınlatması ile olanaklıdır. Marifet adı verilen bu bilgi ancak Tanrı'nın inayetiyle velinin kalbine manevi nurun bırakılması şeklinde oluşmaktadır. Tanrı ile veli arasındaki bilişsel ilişki, güneş ile ışıkları arasındaki ilişki gibidir. Güneş 1şıklarının güneşte kaybolduğu gibi Tanrı'yı en iyi bilen veli de Tanrı'da kaybolmaktadır. Arifler, Tanrı'yı dolaysız bilgiyle; gözleriyle görmeksizin, malumat almaksızın, göz-

31 Hucviri, Ali b. Osman Cullabi, Keşfu'l Mahcub-Hakikat Bilgisi, haz. Süleyman Uludă̆, İstanbul, 1982, s.89.

32 Sufi literatür, akıl ve metin temelli faaliyetlere duyulan güvensizliği analatan hikaye ve şiirlerle doludur. Bu bağlamda büyük sufi önderlerden birinin elini, gençliğinde kelam eğitimi almış olan velilerden Ömer Sühreverdi'nin göğsüne koyup, bütün okuduklarını unutmasını ve bunun yerine göğsünü ilm-i ledun'la(doğrudan Allah vergisi gayb ilmiyle) doldurmasını sağladığı hikaye edilir. Abdulkadir Geylani’nin keramet gösterip, müridi için tehlikeli ve zararlı gördüğü bir felsefe kitabının yazılarını silmesi, kimi sufilerin ise, gördükleri rüyalardan hareketle, değerli kitap koleksiyonlarını ya tahrip etmeleri ya da nehre atmaları gibi örnekler, onların akla ve bilime duyulan güvensizliğinin boyutlarını göstermektedir. Bunun yanında özellikle felsefe, kelam ve fikha yönelik tahkir ve tezyif dolu ifadeler, sufilerin şiirsel literatüründe önemli bir yer kaplar. Senai'nin şu dizeleri bu duruma örneklik teşkil eder:

"İlk madde ve ilk neden gibi sözlerle

Bulamazsin rabbe giden yolu."

"Ebu Hanife aşk dersini vermedi,

Şafii'de de aşka dair rivayet bulamazsın

Hanbeli'nin ise zaten aşktan haberi yoktu,

Maliki de ona dair bir dirayete sahip değildir."

bkz. Schimmel, İslamin Mistik Boyutu, s.34-35. 
lemlemeksizin, tasvir etmeksizin, perdelenmeksizin doğrudan görürler. Ariflerin hareketleri Tanrı tarafından yönlendirilir. Sözleri kendi dilleriyle söylenmiş olsa da Allah'ın sözleridir. Görmeleri Allah'ın görmesidir. ${ }^{33}$ Ariflerin ulaştıkları bu hal, onların tüm yetenek ve eğilimlerinin Allah ile birliği gerçekleştirmeye yöneldiği bir aşamanın sonucudur. Bu aşamaya Yaratan ile yaratılanın temel özdeşliğini gizleyen cehalet perdesinin kalkması da denebilir. ${ }^{34} \mathrm{Bu}$ aşamaya geliş, sufi literatürde aşk kavramıyla temellendirilir. ${ }^{35}$ Kişinin kalbinde doğan ve bilinçli ya da içgüdüsel bir amaçla Allah'a duyulan bu aşk, Allah'ın sıfatlarının dolaysız idraki yani müşahade sonucu meydana gelir. Bu aşkı derinden yaşayan velinin aşkı, sıfatlarından başlayıp Allah'ın zatına ulaştı̆̆ takdirde yeni bir boyut kazanır. Isşte bu boyutta veli, tüm ilahi sıfatları kazanarak Allah'ın "ben bir kişiyi sevdiğimde onun kulakları ve gözleri olurum" durumuna erişir. Sufi teolojinin Tanrı-insan ilişkisini yansıtan bu anlayışta veli Tanrı'yla bütünleşerek ontolojik ve epistemolojik bir birliğe dönüşmektedir. Başka bir ifadeyle Tanrı, velinin şahsinda erimektedir.

Tasavvufi bilgi kuramının kaynağı konumundaki hayal alemi, eşyanın gerçek bilgisini içinde barındıran bir hazine olarak görülmektedir. Hayal gücü, sufi düşüncenin ayakta kalması ve istikrarını sağlayan önemli eylemlerden biridir. Bu düşüncede muhayyile, her an faaliyette olup, rüyalarda olduğu kadar uyanıkken de işlevseldir. Hakikatlerin sembolü olan ve diş dünyadaki varlıkların formlarını muhafaza eden hayal alemi, psikolojik ve metafiziksel bir boyut taşır. Bu alemin, dış dünyadaki varlıkların formlarını kendine göre şekillendirme ve dilediği şekle sokma, duygu ve düşünceleri

33 Attar, Tezkiratü'l Evliya, I/s.127.; Tezkiratu'l-Evliya(Yazma), v.61a-b.

34 Schimmel, İslamin Mistik Boyutları, s.20.

35 Sufi literatürde duygu ve düșüncenin şiirsel anlatımı ve bu anlatım içerisinde işlenen sevgi ve aşk teması ve alegorisi temel bir öneme sahiptir. Bu alegorilere bakıldığında sufilerin zihninde insani ve ilahi betimlemenin kolaylıkla yer değiştirebildiğini görmek mümkündür. Sufi gelenekte aşk, varlıkları birbirine bağlayan ve onları her yönüyle kuşatan ilahi bir ilke olarak düşünülür. Sufi aşk teorisinde, aşık ile maşuk'un(kul ile Tanrı'nın) nihayetinde birleşmesi ve tek bir varlığa dönüşmesi yüce bir gaye olarak görülür. Tanrı'ya yapılan ibadetin temelinde bu yoğun sevgi ve aşk duygusu vardır. Hatta ibadet adeta aşk ile özdeş bir konumdadır. Tanrı'ya yapılan her türlü yakarış ve ibadetin en belirgin göstergesi ve en büyük gayesi bu aşk olgusudur. Aşk kavramı, sufi teolojinin, akıl ve metin teolojilerinden ayrılmasının temel nedenini oluşturur. Kalp teolojisinde aşkın yüce gayesi olarak görülen Tanrı, ne filozofların düşündüğü gibi fail sebep(efficient cause)'tir, ne de kelamcıların aşkın Tanrısıdır. O, kulun kalbinde, ona şah damarından daha yakın olan içkin Tanrıdır. Kalp teolojisinin Tanrı'sı göklere ve yere sığmayan ancak sufinin kalbinde yer bulan aşkın yüce gayesidir. Sufi geleneğin aşk teorisi İbn Arabi’nin şu beyitinde kısaca özetlenmektedir: "Aşk ve muhabbet hakkı için muhakkak aşk sevginin sebebidir. Kalpte aşk olmasaydı, Aşk’a ibadet edilmezdi.” Bkz. İbn Arabi, Fusus, 288. 
somut nesneler biçiminde tasavvur etme ve bu tasavvurlar üzerinde istediği tasarrufta bulunma, hatta bunları dış dünyada somut varlığa dönüştürme, maddi formlara soktuğu zihinsel tasavvurları sanki dış dünyada gerçekten varmış gibi gösterme gibi güç ve işlevleri vardır. Sufi teolojide ruhlar alemi ile görünen alem arasında bulunduğu düşünülen hayal alemi, peygamberliği kapsayacak tarzda kurgulanmıştır. ${ }^{36}$ Peygamberler tarafından tecrübe edilen bazı olayların aynısının hayal gücü aracılığıyla sufi tarafından da yaşanabileceği, peygamberlerin vahiy meleği ile kurdukları ilişkinin aynısının ya da benzerinin sufi tarafından da kurulabileceği vurgulanmaktadır.

\section{Nebi/Resul-Veli}

Sufi teoloji, teolojik algılama biçimini başından beri Hz. Muhammed'in şahsına ve otoritesine dayandırmıştır. Peygamberin ümmi olduğuna; okuma yazma bilmediğine yönelik Kur'an ifadesi ${ }^{37}$ sufi teoloji için hareket noktası oluşturur. Onların her türlü akli bilgiye ve kitaplara karşı mesafeli durmaları, bu ilkeyi anlama ve yorumlama biçimleriyle doğru orantılıdır. ${ }^{38}$ Hz. Muhammed şahsı ve yaşam biçimiyle, sufi teolojinin hal ve makam teorilerinin temelidir. Örneğin Kur'an'ın söz konusu ettiği İsra olayı ve rivayetlere dayalı Miraç, sufiler için Tanrı'ya ulaşmak için çıkılan yolculuğun ilk örneğidir. Bu teolojinin geliştirdiği hal ve makamlardan her biri peygambere atfedilen bir hadisle anlamlandırılmaya çalışılmıştır. Başka bir ifadeyle sufi teolojinin ürettiği her eğilimin, peygamberi bir dayanağı olagelmiştir. İslam düşüncesini oluşturan paradigmalar içerisinde sufi paradig-

36 Sufi hayal gücü sayesinde dilediği kimseyle dilediği şeyi konuşmakta, onu dış dünyada nesnel olarak varmış gibi somutlaştırmaktadır. Hayal aracılığıyla bilgi alışverişinde bulunmaktadır. Örneğin İbn Arabi'ye göre Hz. Muhammed'in Dihye adlı sahabe suretinde gördüğünü söylediği vahiy meleğinin hayal olduğunu ileri sürmektedir. Peygamberin yaşadığı bu olayın aynısının sufi tarafından da yaşanabileceğini iddia etmektedir. İbn Arabi, kendi muhayyilesinin gücünü şu ifadelerle anlatmaktadır: "çok güçlü muhayyilem vardır ki bu sayede sevgim sevgilimi diş dünyada, Cebrail'in Hz. Peygamber'in önünde tecessüm etmesi gibi, gözümün önünde somutlaştırdı. Bu esnada ben ona bakamazdım ama o, bana hitap eder ben ise onu dinler ve ne dediğini anlardım." Bkz. İbn Arabi, Futuhat, II/s.418-429; Afifi, E. A., Muhyiddin İbnu'l Arabi'nin Tasavvuf Felsefesi, çev. Mehmet Dağ, Ankara, 1975, s.118-119.

377 A'raf, 157-158.

38 Kur'an'ın Hz. Muhammed hakkındaki ümmi ifadesine sufiler özel bir önem atfederler. Sufi teolojide bu ifadenin gizli bir anlamının olduğu düşünülmüştür. Onlara göre akla dayalı teolojik spekülasyonlarla ve öğrenimle bozulmamış, tıpkı Meryem'in bakir bedeni kadar saf bir kalbe sahip Hz. Muhammed ilahi kelimenin hazinesi olmaya layıktı. Nitekim mutasavvıflar sadece ilahi birliğin ve biricikliğin simgesi olan elif harfini okumalarına izin veren ümmilikleriyle övünürken, karşılarında, her türlü muhakemeyi dışlayan saf aşkın ve teslimiyetin örneği olan Peygamberi görmüşlerdir. Bkz. Schimmel, İslamın Mistik Boyutları, s.217. 
manın, Peygambere gösterilen sevgi ve hürmetin ${ }^{39}$ en fazla abartıldığı ve efsanevi boyutlara taşındığı bir model olduğu görülmektedir. Nitekim sufiler nazarında o, beşeri nitelikler taşımanın ötesinde, yaratılışın nedeni ve amacı, tanrısal nitelikler de taşıyan mükemmel insan prototipi, tanrısal bilginin ve niteliklerin en mükemmel tarzda göründüğü tinsel bir varlık ve öte dünyada ümmetinin şefaatçisidir.

Diğer teolojik modellerden farklı olarak sufi teolojinin Hz. Muhammed imgesi, güçlü mistik ve mitolojik öğelerle süslüdür. Hz. Muhammed'in diğer insanlar gibi bir beşer olduğu, insanüstü hiçbir nitelik taşımadığı yönündeki Kur'an uyarısının, sufilerce pek de dikkate alınmadığı görülmektedir. Sufi teolojinin karekteristik özelliklerinden biri olan ve metafiziksel bir boyut taşıyan nur ya da ışık teması Onun şahsı dikkate alınarak kurgulanmiştır.

Sufilere göre bütün ruhların kaynağı mutlak nurdur, mutlak nur ise yaratılışın nedeni ve gayesi, yaratılan ilk varlık Muhemmedi nurdur. Sufilerce sıkça kullanılan, "Sen olmasaydın yeri göğü yaratmazdım"40, "Allah’ın yarattığı ilk şey benim ruhumdu"41, "Âdem, suyla çamur arasındayken ben peygamberdim" ${ }^{2}$ bu ve benzeri rivayetler onların metafiziksel peygamber

39 Kur'an'ın özellikle Hz. Muhammed'in beşer ve elçi oluşuna yönelik uyarısının ciddi anlamda ihmal edilmesi sadece sufi geleneğe özgü değildir. Müslüman kültürün konu hakkında bu tarz bir ihmal ve duyarsızlık içinde olduğunu söylemek mümkündür. Kur'an'ın Hz. Muhammed hakkında belirlediği tasarımın ana teması, Onun bir elçi olarak ilahi mesajları insanlara iletmekle görevli olduğundan ibarettir. Ancak Onun ölümünden kısa bir süre sonra Müslümanlar bu Kur'an tasarımının ötesinde, Ona insanüstü nitelikler atfetme arayışına girmişlerdir. Onun sözleri, hal ve hareketleri, giyim kuşamı, tercih ettiği yiyecekler, özellikle yaşamının şekilsel boyutu her Müslüman birey için ideal hale gelmiştir. Artık Peygamber ve uygulamaları örneklik oluşturmaktan çıkarak, Kur'an'la eşdeğer zaman ve mekân dişı bir ölçütlüğe dönüşmüștür. Mistik ve mitolojik hikayelerin de eklemlenmesiyle Peygamberin hayatı farklı bir boyut kazanmıştır. Kur'an, Onun Kur'an'dan başka mucizesinin olmadığını ve yegâne görevinin de ilahi mesajları insanlara iletmek olduğunu bildirmektedir. Buna bağlı olarak Hz. Muhammed, akıl dışı her türlü mitolojik hikâyeyi ve özellikle kişiye tapınmayı şiddetle reddetmiştir. Ancak çok geçmeden $\mathrm{O}$, etrafı efsanevi hikâyelerle ve hissi mucizelerle çevrili, insanüstü nitelikler taşıyan bir ideal kişiliğe dönüşmüştür. Görünürde İslam'ın kalbi, ilahi mesajları insanlara ileten elçi değil, elçinin getirdiği Kur’an’ın kendisi olsa da, peygamber'in her yönüyle kişiliği dinsel yaşamın amacı haline dönüşmüştür. Bunun iyi niyete ve Peygambere duyulan sevgiye dayalı olması, gerçeği değiştirmemektedir.

40 Bkz. Sağani, el-Mevduat, Beyrut, 1985, s. 14, no: 78; Aliyyu'l-Kari, el-Esraru'l-Merfua, thk. M. B. Lutfi es-Sabbağ, Beyrut, 1986, s.288, no: 385; Hz. Muhammed'in, Allah'ın nurundan yaratıldığına ve Onun kainatın yaratılış nedeni olarak sunulmasına yönelik rivayetlerin değerlendirilmesi için bkz. Erul, Bünyamin, "Uydurma Rivayetlerde Peygamber Tasavvuru”, İslam'ın Anlaşılmasında Sünnetin Yeri ve Değeri adlı eser içerisinde, Ankara, 2003, s.419-435.

41 Leknevi, el-Asaru'l-Merfua, thk. M. Said b. Besyuni Zeğlul, Beyrut, 1984, s.42-43.

42 Sağani, ed-Durru'l-Multekat fi Tebyini'l-Ğalat, s.43, no: 73.; İbn Arrak, Tenzihu'ş-Şeriati'lMerfua, thk. A. Abdullatif- A. M. Es-Sadik, Beyrut, 1981, I/s.341. 
kurgusunun kanıt teşkil eder. Hz. Muhammed'e duyulan abartılı sevgi sufi teolojinin ışık temasıyla birleşerek, hiyerarşik yapıya uygun olarak, aşağıdan yukarıya doğru bir seyir izler. Sırasıyla manevi rehbere(şeyh/veli) duyulan aşk ve sevgi peygamber sevgisine peygamber sevgisi de Tanrı sevgisine ulaştırır. Bu süreç sufi literatürde fena fi'ş-şeyh, fena fi'r-resul ve fena fi'llah kavramlarıyla ifade edilmektedir. Buna göre Tanrı'ya giden yolculukta öncelikle peygamberin temsilcisi şeyhte yok olmak, sonra peygamber'de, daha sonra da Tanrı'da yok olmak mümkün hale gelir.

İsra suresinin başlangıcında değinilen Hz. Muhammed'in gece yolculu$\breve{g u}$, efsanevi unsurlarla süslenerek ve herkes için geçerli k1lınarak, sufi düşüncedeki ilahi huzura yükselişin örneği olmuştur. Miraç esnasında Hz. Muhammed'in yaşadığ 1 varsayılan olaylar, çeşitli mitolojik öğelerle süslenerek her sufinin tecrübe etmesi gereken hal ve makamlara dönüşmüştür. Tasavvuf ehli, miraç terminolojisini, herhangi bir kasıt ve zorlama olmaksızın kendinden geçme hali olan vecdleri sırasında yaşadıklarına uyarlamıştır. Pek çok dinde ve mitolojide çeşitli şekillerde varolan göksel aleme yükseliş tasavvuru ${ }^{43}$, sufi teolojide zamandan ve bütün maddi unsurlardan sıyrılarak İlahi aşkın sırrına ulaşma gayesini ifade eder. Tanrı ile insan arasında hiyerarşik olarak, üç varlık alemi belirleyen sufiler, miracın, ruhsal alemle yani alem-i misalle maddi alem yani alem-i şuhud'un arasını bağlayan adeta bir merdiven işlevi gören berzah ya da melekut aleminde gerçekleşen bir yolculuk olduğunu düşünürler. ${ }^{44} \mathrm{Bu}$ yolculuk, sufinin tek başına Tanrı ile yüz yüze bağlantı kurması ile sona erer. ${ }^{45}$

Sufi geleneğin insani düzlemde belirlemiş olduğu hiyerarşik yapının en üst derecesini velilik makamı oluşturur. Bu derece Tanrı'yı bilmeyle doğru orantılıdır. Tanrı'yı en iyi bilen ve tanıyan kişi olarak veli, mistik yaşam tecrübesinde belirli bir makama ulaşan, bağlılarına yol gösterici konumda

43 Göksel yolculuk tasavvuru, başta Hıristiyanlık ve Yahudilik olmak üzere pek çok din ve kültürde önemli yer işgal eder. Yahudi geleneğinde İdris, İbrahim, Musa ve İşaya gibi peygamberlerle bazı tarihi şahsiyetlerin bu göksel yolculuğu tecrübe ettiklerine inanılır. Özellikle melek Yahoel tarafından göksel bir vasıtayla bulut içinden göğe yükseltilen Hz. İbrahim'in, Tanrı'nın tahtını müşahade edişiyle ilgili tasvirler Yahudi literatüründe önemli yer kaplar. Hıristiyanlığa göre ise Hz. İsa çarmıha gerildikten sonra mezarından çıkıp ilahi aleme yükselmiştir. Bunun yanında bazı rivayetlerde Pavlus'un Kudis'e doğru giderken melek eşliğinde göğe yolculuk yaptığı belirtilir. Bkz. Gündüz, Şinasi, Dinlerde Yükseliş Motifleri ve İslam'da Miraç, Ankara, 1996, s.41-64.

44 ed-Dihlevi, Şah Veliyullah, Huccetullahi'l-baliğa, nşr. M. Şerif Şükker, Beyrut, 1992, I/115-116.

45 Sufilere göre bu yolculuğun kritik sınırı sidretu'l müntehadır. Melekler dahi bu sınırı geçmeye muktedir değildir. Bu sınırın ötesinde İlahi aşkla karşılaşma ve vakit geçirme vardır. Sufi tıpkı peygamberin tecrübesinde olduğu gibi bu sınırı tek başına geçerek Tanrı'yla baş başa kalır. Bkz. el-Cilani, el-İnsanu'l-Kamil fi Marifeti'l-Evahir ve'l-Evail, Ezher, 1316, II/s.7-8. 
bulunan ve bazı özel güçleri kendinde barındığına inanılan kişi demektir. Bu yönüyle veli, baştan aşağı mükemmel insan yani insan-1 kamil modelini temsil eder. Bu mükemmel modele aşağıdan yukarıya doğru ilerleyen ruhsal bir yolculukla ulaşılır. Bu yolculuk sufi gelenekte makamlar teorisini ortaya çıkarmıştır.

Çeşitli aşamalardan oluşan bu makamlar teorisi çoğu zaman Kur'an'dan transfer edilen tövbe, zühd, sabır, şükür, tevekkül ve rıza gibi dini-ahlaki terimlerle ifade edilmiştir. Bu terimler Kur'an kaynaklı olsa da, bağlam, anlam ve içerik yönünden yeniden kurgulanmıştır. Bu kurgu sufinin tecrübe ettiği psikolojik ve irfani hallere göre biçimlenmiştir. Aşağıdan yukarıya insandan Tanrı'ya gidişi ifade eden bu makamlar ve haller teorisi Tanrıinsan ayırımının yok olduğu fena aşamasıyla son bulur. Fena aşamasında tanrısal olanla insani olanı birbirinden ayırma olanağı kalmaz. Bu aşamada insan, bütün beşeri niteliklerini yitirerek ilahi niteliklerle donanır. ${ }^{46}$ Sufinin ulaştığı bu makam velilik makamıdır. Kur'an'dan ödünç alınan veli kavramına özellikle Doğu Hıristiyan mistisizminin, gnostisizmin ve Yeni-Eflatunculuğun tanrısallığın insanda tecellisi şeklindeki içeriği yüklenmiştir. ${ }^{47}$ Tasavvufi literatürde velinin peygambere veliliğin ise peygamberliğe paralel özellikler taşıdığı söylenebilir. Hatta bazen bu makama peygamberlikten daha üstün bir değer atfedilir. Bu durum insanda, sufi peygamber alg1sının dindeki peygamber algısına alternatif oluşturduğu hissini uyandırır.

Sufi teolojinin içeriğini çevre inanç ve kültürlerden transfer ettiği Kelime ya da Kelim kavramı, hem Tanrı hem peygamberler hem de veliler için ortak bir isimlendirmedir. Kelime'nin idrak etme, yaratma ve alemi yönetme işlevleri yanında ilahi bilgiye ya da Batıni marifete kaynaklık etmek gibi işlevi de vardır. Kelime, peygamber ve velilerin vahiy, ilham ve keşif yoluyla elde ettikleri bilgilerin kaynağı Muhammedi Hakikat yani Hakikat-1 Muhammediye'dir. Sufi gelenekte evrendeki her bir varlık kelime olarak isimlendirilse $\mathrm{de}^{48}$, ilahi bilinci tam ve kapsayıcı bir tarzda yansıtmalarından

46 Tanrı'ya giden bu ruhsal yolculuk sonucunda ulaşılan tanrısal makam, sufi gelenekte nihai hedef olarak belirlenmiştir. İnsani bilincin tanrısal bilince dönüştüğü bu aşama, pek çok sufinin "Ben Hakk'ım", "Hamd benim İçindir", "Benim alemim Hz. Muhammed'inkinden daha üstündür", "Ben Uluyum" gibi sözler sarfettiği vecd halini ifade eder. Sorumluluk gerektirmeyen bu ifadelere tasavvufi literatürde şatahat adı verilir.

47 Fazlurrahman, İslam, s.170.

48 "De ki; Rabbimin sözlerini yazmak için deniz mürekkep olsa ve bir o kadar da eklesek, Rabbimin kelimeleri bitmeden deniz tükenir.”(18 Kehf, 109) ayetinden hareketle sufiler, evrenin natık şeylerin toplamı olduğunu düşünürler. Kaşani kainatı kelimeler şeklinde isimlendirmektedir. Ona göre harfler ve kelimeler insan için ne ifade ediyorsa evren de ilahi zat için onu ifade eder. Evren "nefh" şeklinde ifade edilen ilahi nefesten doğduğu için, onu kelimeler şeklinde 
dolayı o, özellikle peygamber ve veliler için kullanılır. Kelime olarak Hz. Muhammed ile diğer peygamber ve veliler arasındaki ilişki bütün-parça ilişkisidir. Zira o, onlarda da tecelli eden ilahi isim ve sıfatları kendi şahsında mükemmel ve kapsayıcı bir biçimde barındırır. Başka bir ifadeyle o, Muhammedi Hakikate, diğer peygamber ve veliler ise, Muhammedi Surete karşılık gelir.

Sufi literatürde Hz. Muhammed'e atfedilen, "Bana cevamiu'l-kelim verildi" ${ }^{4}$ şeklindeki rivayet, onunla diğer peygamber ve veliler arasındaki ilişkiyi anlatır. Burada kelim ifadesi Hz. Muhammed dışındaki peygamber ve velileri, kelimeler toplamı ise Muhammedi hakikati ifade eder. İbn Arabi Fusus adlı eserinde her bir peygamberi kelime olarak isimlendirmekte ve onların her birinin ilahi bir isimle ilişkili olduğunu ${ }^{50} \mathrm{~Hz}$. Muhammed'in ise bütün ilahi isimleri şahsında barındırdığını düşünmektedir. Bu durum velilerin diğer peygamberlerle eşit düzeyde olduğuna kanıt oluşturur. Zira veliler ile peygamberler aynı epistemolojik ve ontolojik kaynağın, yani Muhammedi Hakikatin ortak varisleridir. Velayetin nübüvvete eşdeğerliği, sufilerce kullanılan, "Ümmetimin alimleri yani velileri, İsrailoğullarının peygamberleri gibidir." şeklindeki rivayetle pekişmiş olur.

Sufi peygamber algısına kaynaklık eden ve insan-1 kamil teorisine temel oluşturan Hakikat-1 Muhammediye ${ }^{51}$ kavram1, Hz. Muhammed'in ontolojik konumunu belirlediği gibi onun diğer peygamber ve veliler arasındaki yerini de tayin eder. Önde gelen sufi önderler Hz. Muhammed'in bütün peygamberler arasında ayrı bir yerinin olduğunu düşünür. Onlar açısından Hz. Muhammed'in tarihin bir döneminde Allah tarafından bir elçi olarak seçilmesinden ve ilahi mesajları tebliğle görevlendirilmesinden daha önemli

isimlendirmek yanlış olmaz. Harflerden meydana gelen kelimeler, benliğin işaret ve sembolleridir. Yaratılmış varlıklar da Tanrı'nın işaret ve sembolleridir. Bütün peygamber ve veliler ise, Muhammedi hakikate işaret eden kanıt ve sembollerdir. Bkz. İbn Arabi, Futuhat, I/s.153 vd., 232 vd.; Kaşani, Şerhu Fususi'l-Hikem, Kahire, 1309, s.13-17, 275.

49 Buhari, Cihad, 122, Ta’bir, 11, 22, İtisam, 1; Müslim, Mesacid, 8; Ahmet b. Hanbel, Müsned, $\mathrm{II} / 314$

50 İbn Arabi'ye göre nutk sahibi herkes, ister nebi ister veli olsun, ilahi isimlerden birisinin etkisi altındadır. Onlardan her birisinin bilgisine, ilahi bir isim kaynaklık etmektedir. Bkz. İbn Arabi, Fusus, s.62-66; el-Futuhat, I/s.389-397, 415-426,

51 Sufi literatürde mana alemi ve Hazret-i Amaiyye şeklinde de ifade edilen Muhammedi Hakikat, kalem ve levhin, tabiatın, varlık olarak Ademe varıncaya kadar cismin hakikatlerini kapsar. Bütün bunlar, mana alemindeki varlı̆̆ın ayni(maddi) hale gelmiş şekilleridir. Sufilere göre teferruat ve çokluk itibariyle Hazret-i Amaiyye sıfatla ilgili yedi ismin hakikatini içerir. Bunların en kapsamlısı hayat hakikatidir. Sonra nebi ve resullerin, kutup adı verilen kamil insanların ve yedi abdalın hakikatlerini içerir. Bunların tümü Muhammedi Hakikatin tafsilidir. Bkz. İbn Arabi, Futuhat, I/s.345 vd.; İbn Haldun, Tasavvufun Mahiyeti, haz. Süleyman Uludă̆, İstanbul, 1977, s.161, 246. 
olan husus, onun ezeli bir tabiata sahip olmasıdır. Sufi teoloji onun ezeli bir tabiata sahip oluşunu, "Adem henüz balçıkla su arasındayken, yani insanoğlu henüz yaratılış sürecindeyken ben peygamberdim" rivayetine dayandırmaktadır. Böylece Hz. Muhammed ilahi bilinçle özdeşleşmesinden dolayı Tanrısal, yaratılmış alemle ilişkisinden dolayı da beşeri nitelikleri şahsında taşıyan insan-ı kamil modelin biricik temsilcisi konumundadır. Bu durumda insan-ı kamil örneği Tanrı'nın görünen alemde tecelli eden bilincinden başka bir şey değildir.

Sufi teolojide Hz. Muhammed'in aynı anda tanrısallı̆̆ı ve beşeriliği temsil ettiği iddiası, Nur-1 Muhammediye ya da Ruh-1 Muhammediye ${ }^{52}$ kavramlaryyla da ifade edilmektedir. Sufi önderler buradaki ruhun ya da nurun henüz bütün var olanların yaratılmasından önce var olduğunu savunurlar. $\mathrm{Bu}$ yönüyle Muhammedi Nur ya da Muhammedi Ruh, ezeli ve zaman dışıdır. Alemin yaratılışının temelini oluşturan ve ilahi bilinç olarak da yorumlanan bu ezeli ve zaman dışı Nur, sırasıyla bütün peygamberlerde tecelli etmiş, Hz. Muhammed'in şahsında ise mükemmel bir tarzda ilk defa belirgin kılınmıştır(taayyün-i evvel) ${ }^{53}$. Böylece Hz. Muhammed, bir yandan tanr1sal, yani ilahi bilinci temsil etmesi yönüyle diğer yandan beşeri boyut taş1ması özelliğiyle genelde tüm varlıklardan özelde ise diğer peygamberlerden üstün olarak görülmektedir.

Sufi teolojinin insan-1 kamil teorisi, peygamberliği ve velayeti içine alacak tarzda tasarlanmıştır. Başka bir ifadeyle peygamberlik ve velilik, insan-1 kamil teorisi kapsamında, epistemolojik ve ontolojik yönden özdeşleşmekte

52 İbn Arabi başta olmak üzere önde gelen sufilerce üretilen Nur-1 Muhammediye ya da Ruh-1 Muhammediye kavramları, Plotinus felsefesinde Mutlak Tek'den sudur eden Akl-1 Evvel'e karş1lık gelmektedir. Buna göre Akl-1 Evvel'in, sudur ettiği mekan olarak pasif boyutu, kendinden sudur edenlerle ilgili olarak da aktif boyutu bulunmaktadır. Böylece $O$, kendi üstünde bulunan varlık düzeyine, yani Tanrı'ya karşı pasif, kendi altında bulunan varlıklara karşı ise aktiftir. Sufi teolojide bu pasiflik kulluğa(ubudiyete), aktiflik ise Rablığa(Rububiyete) dönüşmektedir. Bkz. el-Cilani, el-İnsanu'l-Kamil, I/s.30-32; Afifi, Ebu'l Ala, İslam Düşüncesi Üzerine Makaleler, çev. Ekrem Demirli, İstanbıl, 2000, s.78-88; Izutsu, Toshihiko, Sufism and Taoism,Tokyo, 1983, s.238.

$53 \mathrm{~Hz}$. Muhammed'i en üst düzeyde cem etme yeteneğine sahip varlık olarak gören Kaşani'ye göre, "O, Teklik mertebesindeki Zat(Tanrı)'ın, başka varlıklarda tecelli etmesinden önce, kendisini yansıttığı ilk taayünüdür. Sayıları sonsuz olan diğer belirgin kılınmalar(taayünat)'ın hepsi gerçekte Hz. Muhammed aracılığıyla kuvveden fiile çıkmıştır. Hakk'ın bütün tecellileri hiyerarşik bir biçimde sıralanır. Bu hiyararşi doğrultusunda Hz. Muhammed, hiç biri dışarıda kalmayacak bir tarzda, bütün bu belrgin kılınmaları(taayünat) kendinde toplamıştır. Bu bakımdan O, bütün varlık aleminde tektir. Bu hiyerarşide ona rakip ya da onunla eşit düzeyde hiçbir varlık yoktur. Onun üstünde Mutlak Tekliği ile bilinen, sıfat, isim, tasvir ya da nitelendirme açısından her türlü taayünden bağımsız olan Zat bulunmaktadır.” Bkz. Kaşani, Şerhu Fusus, s.427. 
ve eşdeğer kabul edilmektedir. Sufi teorisyenlere göre Mutlak anlamda varlıkların en mükemmeli Tanrı, insanı kendi suretinde yaratmıştır. ${ }^{54}$ İnsanın Tanrı'nın sureti ve O'nun isim ve sıfatlarının tecelli ettiği bir varlık olması, ona diğer varlıklarda olmayan bir mükemmellik katmaktadır. Bu mükemmellik tam anlamıyla peygamber ve velilerde gerçekleşmektedir. Peygamber ve veli, kendilerinde ilahi isim ve sıfatlar tecelli etmesi dolayısıyla eşdeğerdir. Bu eşdeğerliğin bir başka gerekçesi, her ikisinin de keşf mertebelerini tecrübe ederken tanrısal olanla birleşmeleridir. Zira Tanrı bu süreçte peygamber ve velinin şahsında kendisini kendisiyle bilmektedir. Bu, hem peygamberin hem de velinin bilişsel ve varoluşsal yönden Tanrı'yla birleşmeleri anlamına gelir. Başka bir ifadeyle peygamber ve veli, hem varlığı hem de marifeti itibariyle, yani hem Tanrı'nın sureti üzere yaratılmış olmaları hem de ilahi zatın bilincinin varisleri olması itibariyle özdeş ve eşdeğerdir.

Sufi teolojide peygamber/veli eşdeğer ve özdeşliğinin, bazen veli lehine bozulduğu da bir gerçektir. Pek çok sufi teorisyen nebi, resul ve veli kavramları içerisinde en geniş anlam alanının veli kavramına ait olduğunu düşünür. ${ }^{55}$ Nebi kavramı resul kavramını içerirken veli kavramı her ikisini de kapsayacak ölçüde geniş bir anlam alanına sahiptir. Her resul aynı zamanda bir nebi, her nebi ise aynı zamanda bir velidir. Sufi gelenek veli kavramına nebi ve resul kavramından daha fazla değer atfetmektedir. Çünkü ne nebi ne de resul kavramı Tanrı'nın isimleri arasında yer almazken veli kavramı, ilahi isimlerden biridir. Tanrı kendisini nebi ve resul olarak değil, veli olarak isimlendirmektedir. ${ }^{56}$

54 Sufi literatürde sıkça kullanılan ve makrokozmos(alem-i kebir)-mikrokozmos(alem-i sağir) ayırımına temel oluşturan, "Allah, ademi kendü suretinde yarattı" şeklindeki rivayet, insan-1 kamil teorisinin en önemli dayanaklarından biridir. İnsan, varlığın tüm anlam ve özelliklerinin kendisinde gerçekleştiği yegâne varlıktır. Bu nedenle o, insan-1 kamil olarak isimlendirilmektedir. İnsan-1 kamil, Tanrı'nın kendisini tam anlamıyla açtı $\breve{g}_{1}$ ve yansıttı $\breve{1}$ biricik modeldir. Tanrı'nın açılımına ve yansımasına mekân oluşturan insan-1 kemil, sufi literatürde peygamberler ve velilerle temsil edilir. Bkz. el-Cilani, el-İnsanu'l-Kamil, II/s.44-48, 85. vd.; Izutsu, Sufism and Taoism, s.218 vd.; Afifi, İslam Düşüncesi, s.90 vd.

55 İbn Arabi kendine özgü bir velayet doktrini geliştirerek, bütün peygamberlerin aynı zamanda veli olduğunu; ancak her bir peygamberin velayet yönünün nübüvvet yönünden üstün olduğunu düşünür. Ona göre bütün peygamber ve veliler Muhammedi Ruh ya da Muhammedi Hakikatin görünüşleridir. Tarihteki Muhammed, peygamberlerin mührü, yani sonuncusu(hatemu'l enbiya) olması nedeniyle diğer bütün peygamberlerden üstündür. Bundan sonra İbn Arabi, peygamberle paralel özellikler taşıyan hatta ondan da üstün niteliklere sahip hatemu'l evliya doktrinini geliştirir. Evliyaların mührünün, yani sonuncusunun Muhammedi Ruhun mükemmel görünüşünü temsil ettiğini ileri sürer. İbn Arabi kendisinin bu mührün varisi olduğunu, hatta daha ileri giderek bu mührün kendisi olduğunu ifade eder. Bkz. İbn Arabi, Fusus, s.62-63.; elFütuhat, I/s.433 vd., II/s.78, 204 vd.; Kaşani, Şerhu Fusus, s.252.

56 İbn Arabi, Fusus, 171-172.; Kaşani, Şerhu Fusus, s.251 vd. 
Derece bakımından velinin mi yoksa nebinin mi üstün olduğu sorunu, Sufi teolojinin tartışma konularından biridir. Bazı sufi teorisyenler nebinin veliden üstün olduğu konusunda taviz vermek istemeseler $\mathrm{de}^{57}$, velinin nebiden daha üst bir derecede olduğu fikri sufi literatürde yaygın bir kabul olarak durmaktadır. Hatta bu konuda velinin sarhoşluğunun(sırrı sekr), peygamberin ayıklığından(sahv) üstün olduğunu düşünenler olmuştur. Zira peygamber, Tanrı'yı müşahadede kaybolmayıp, Tanrı'nın iradesini ümmetine bildirmek için geri döner.

Sufi teoloji peygamberliği, nübüvvet-i teşriiye ve nübüvvet-i- velaye ya da nübüvvet-i amme ${ }^{58}$ biçiminde ikiye ayırarak, peygamberlik görevinin velilik aracılığıyla devam ettiğini savunur. Zira dinin söz konusu ettiği peygamberlik ve elçilik tarihe bağlı olup süreklilik taşımaz, hatta zamanla unutulması ve ortadan kaybolması bile söz konusu olabilir. Oysa velilik, hem Tanrı'nın hem de insanın ortak adı olması nedeniyle tarih dışı olup, ortadan kalkması düşünülemez. Tanrı'nın ezeli ve ebedi oluşu, veliliğin de sonsuza kadar devamını gerekli kılar. Evrende velilik derecesine yükselmiş tek bir kişi kaldığı sürece-ki böyle bir kimsenin her çağda var olması söz konusudur- velilik de ebediyete kadar devam edecektir. ${ }^{59}$

57 Peygamberin veliye üstün olduğunu savunan sufi teorisyenler, veliliğin sonunun peygamberliğin sadece başlangıcı olduğunu düşünürler. Onlara göre her peygamber, kendi içinde bir velilik yönüne sahiptir. Veli aşamalı olarak daha yüksek bir yakınlık derecesine ulaşmaya çalışabilir, ancak onun erişebileceği en yüksek düzey manevi bir yükseliştir. Bu ise ancak peygamberin bedeniyle gerçekleştirdiği yükselişe karşılık gelir. Velayetin son aşaması, velinin ruhunun peygamberin bedenine benzemesidir. İşte bu noktada velayet sona erer, peygamberlik başlar. İbn Arabi, Fusus, 172-174.; Schimmel, İslamin Mistik Boyutları, s.202.

58 Sufi literatürde Nübüvvet-i teşriiye, tarihin çeșitli dönemlerinde Tanrı'nın insanlar arasından özel olarak seçtiği, kendisine vahiy gönderdiği, insanları uyarmak, aydınlatmak, müjdelemek ve doğru yola çağırmak için görevlendirdiği elçinin peygamberliğidir. Burada yeni bir şeriatın ihdası söz konusudur. İsa, Musa ve Muhammed'in peygamberliği, bu türden bir peygamberliktir. Zira onlar, herhangi bir peygamberin şeriatını takip etmiş değildirler. Her biri yeni bir şeriat getirmiştir. Bu peygamberlik türü, Hz. Muhammed'le son bulmuştur. Sufilerin nübüvvet-i velaye ya da nübüvvet-i amme dedikleri peygamberlik türü ise, Allah'ın seçkin kulları arasında peygamberlik konumuna yükselmiş olan velilerin peygamberliği, yani velayettir. Bu peygamberlik türü tarih üstü olup evrenseldir, ezelden ebede devam eder. İbn Arabi'nin mutlak velayet olarak da adlandırdığı bu peygamberlik türünde Tanrı, isim ve sıfatlarını sufiye vererek, onun koruyucusu ve dostu olmaktadır. Velayet peygamberliğinde, insan-1 kamil olarak veli, Tanrı tarafından yönlendirilmektedir. Hz. Muhammed'ten önce velayet peygamberliğini icra edenlere resul denmekteydi. O'ndan sonra da bu görevi yürütenler vardır ve bunlar da O'nun suretidirler. Veliler bu peygamberliği gerçekleștirirken bağımsız olmayıp, Hz. Muhammed'in takipçileri ya da varisleridir. Örneğin Beyazıd-1 Bestami, Cüneyd-i Bağdadi, Abdulkadir Geylani ve İbn Arabi bu türden peygamberliği icra eden peygamberlerdir. Bkz. İbn Arabi, Futuhat, I/s.437. Fusus, 170 vd.; Kaşani, Şerhu Fusus, s.251 vd.; el-Cilani, el-İnsanu'l-Kamil, II/s.85 vd.; Dar, B. A., "el-Cili", İslam Düşünce Tarihi içerisinde, İstanbul, 1991, III/82-83.

59 Önde gelen sufi teorisyenlerden İbn Arabi, veli isminin dünyada ve ahirette Allah'nn kulları üzerinde cari olacak bir isim olduğunu, bu yönüyle de sonsuzluk özelliği taşıdığını ileri sürmüş- 
Sufiler dinin ortaya koyduğu peygamberliği-ki onlar bunu şeriat peygamberliği olarak görürler- gelişmiş bir velayet aşaması olarak kabul ederler. Manevi yükselişi hiyerarşik olarak aşamalara ayıran sufi teorisyenler, yedinci aşamanın yakınlık(kurb) olduğunu ve bunun büyük velayete karş1lık geldiğini düşünürler. Bu aşama kendi içerisinde dört dereceye ayrılır. Bunlardan birincisi, Allah'a dost olma(halilullah), ikincisi aşk(hubb), üçüncüsü mühür(hatem), dördüncüsü ise kulluk(abdiyyet)'tur. Sufi teolojide bu aşamalardan birincisi Hz. İbrahim için, diğerleri ise Hz. Muhammed için geçerlidir. Zira Tanrı, Onu bu isimlerle nitelendirmiştir. Hz. Muhammed dördüncü aşamada, yani kulluk aşamasında peygamber yapılmış ve insanlara gönderilmiştir. Bu aşamaya gelmeyi başaran insanlara da kul denmiş ve onların Hz. Muhammed'in her yerde suretleri olduğu düşünülmüştür.

Sufi teolojide veli adı verilen bu insanların da peygamber olduğu, ancak onların peygamberliklerinin Hz. Muhammed'in peygamberliğinden sonra söz konusu olduğu belirtilmiştir. Sufiler, "Ölümümden sonra gelecek kardeşlerime selam olsun" rivayetine dayanarak bu kişilerin Hz. Muhammed'in kardeşleri olduğunu varsaymışlardır. Söz konusu peygamber-velilerin peygamberlikleri tarih üstüdür. Onların peygamberliğe yönelik bilgileri dolaysız olup ilahi kaynaklıdır. ${ }^{60}$ Bu bağlamda velayet en genel anlamda Tanrı ile insan arasında özel bir ilişkidir. Velayet peygamberliği ise bu özel ilişkinin bir boyutunu oluşturur. Bu özel ilişkinin diğer boyutları ise şeriat peygamberliği ve elçiliktir. Bu nedenle hem nebi hem de resul, peygamber olmakla birlikte velidir. Ancak velayet yönü peygamberlik yönünden daha baskındır.

Sufi teolojinin velayet peygamberliği tasarımı, Müslüman kültürü içerisinde pek çok kimsenin peygamberlik iddiasına zemin oluşturmuştur. Ayrıca Sünniliğin peygamberliğe yönelik, her resulun aynı zamanda nebi, ancak her nebinin resul olmadığı, yönündeki formülasyonu muhtemelen bu tasarımın bir yansımasıdır. Sufiliğin, ilahi hakikatlerden haber vermeyi peygamberlik ölçütü, peygamberliği ve elçiliği de velayetin çeşitli yönleri olarak belirlemesi, peygamberlik iddiasında bulunma ya da birilerini peygamber olarak ilan etme girişimlerine kapı aralamıştır denebilir. Örneğin sufi temsilcilerden Niyaz-i Misri'nin, Hz. Muhammed'in torunları Hz. Hasan ve

tür. Ona göre nübüvvetin ve risaletin sona ermesi nedeniyle, Tanrı'dan başka insana özgü kılınmış herhangi bir isim de kalmamıştır. Ancak Tanrı, yeni bir şeriat getirmeyen nübüvvet-i amme'yi ya da velayet peygamberliğini insanlara lütfederek miras bırakmıştır. Bkz. İbn Arabi, Fusus,s. 171.; Futuhat, I/s.434; Kaşani, Şerhu Fusus, s.252.

60 Dar, B. A., "el-Cili", III/83. 
Hz. Hüseyinin peygamber olduklarını iddia etmesi ${ }^{61}$, sufi peygamberlik tasavvurunun bir sonucudur.

Peygamberliği teşri peygamberlik ve velayet peygamberliği olmak üzere ikiye ayıran sufi teorisyenler, veliliği de genel(velayet-i amme) ve özel(velayet-i hassa) şeklinde ikiye ayırırlar. Genel velilik, Tanrı'ya gönülden bağlı olan ve onun buyruklarına uymada maksimum özen gösteren samimi inananların velayetidir. Özel velilik ise, beşer düzlemden tanrısal düzleme doğru yola çıkan, bu yolculukta pek çok aşamayı ve dereceyi başarıyla tamamlayan ve sonunda Tanrı'da yok olan yani fena bulan, Onunla baki olan kimselerin velayetidir. ${ }^{62}$ ilk defa dokuzuncu asrın büyük sufi teorisyeni tarafından ortaya atılan ve sistematize edilen hatemu'l evliya fikri, beraberinde Şia'nın imamet nazariyesine benzeyen masum velilik hiyerarşisini doğurmuştur. Bu velayet doktrinine göre evrenin bütünlüğü, sürekliliği ve düzenli işleyişi çeşitli derecelerde bulunan ancak görünmeyen veliler sayesinde sağlanmaktadır. Hiyerarşik bir yapı taşıyan bu velayet teorisine göre, en yüksek manevi otorite kutb veya gavs adı verilen kişidir. Bu otorite, nukab (nakipler), ebdal (varisler), evtad (kazıklar), amaid (sütunlar), ebrar (dindarlar), ahyar(hayırlılar) adı verilen belirli sayıda gizli velilerle çevrelenmiştir. Sufi teorisyenler bütün evrenin bu otoritenin çevresinde döndügüne inanmaktadırlar. Onlara göre bu otorite ve veliler hiyerarşisi olmasaydı, evrenin bütünlüğünden, düzeninden ve sürekliliğinden söz edilemezdi. ${ }^{63}$ Sufi teolojinin bu kurgusunda velilik, Tanrı-evren-insan ilişkisi ve bu ilişkiden doğan gerçekliklerin kusursuzca bilinmesini içerir.

Velilik konumuna yükselmiş bir kimse, sıfatlarıyla ve zatıyla Tanrı'da yok olarak Onun sıfatları ve zatına büründüğünün bilincindedir. İlahi bilinçle özdeşleşen ve bunun farkında olan velinin, nebi veya resul ile karşılaştırılması olanağı kalmaz. Zira peygamber ya da elçi beşeri düzlemle

61 Aşkar, Mustafa, Niyaz-i Misri ve Tasavvuf Anlayışı, Ankara, 1998, s.268 vd.

62 Söz konusu ayrıcalık taşıyan özel veliliğin olmazsa olmaz şartı ve niteliği Tanrı'da fena ve beka bulmaktır. Tanrı'da yok olma ve Onunla sonsuzluğa kavuşma üç aşamada gerçekleşir. İbn Arabi velinin yaşadı̆̆ını düşündüğü bu aşamaları, tahalluk, tahakkuk ve taalluk şeklinde adlandırmaktadır. Ona göre tahalluk aşamasında veli, kendi beşeri sıfatlarından sıyrılarak ilahi sıfatlarla sıfatlanmaktadır. Tahakkuk aşamasında ise veli, kendi beşeri zatını Tanrı'da yok ederek Tanrı'nın zatıyla zatlanır. Taalluk aşaması ise, velinin sıfatları ve zatıyla bir bütün olarak Tanrı'ya iltihak etmesi, ilahi bilinci paylaşmasıdır. Artık bu şamada veli tanrısal bilince bürünerek sonsuz bir varlığa dönüşmektedir. Onun ilahi bilince bürünen idrakinde insan olmaklığa ait hiçbir iz kalmamıştır. Sahip olduğu yegane bilinç, sıfatları ve zatıyla yok olduktan sonra, İlahi zatta yaşamaktadır. Bu bilinçlenme ile birlikte, ne varlığı kendi varlığı, ne de fiilleri kendi fiilleridir. Velinin varlığı ve fiilleri artık Tanrı'nındır. Bkz. İbn Arabi, Fusus, 173-174.; Kelabazi, Taaruf, s.111.

63 İbn Arabi, Futuhat, I/s.442 vd. 
sıkı sıkıya bağlı bir durumdadır. Başka bir ifadeyle peygamberlik sadece bu dünyayla ilgili bir olgudur. Zaten peygamberlerin insanlara ilettikleri ilahi mesajların nihai gayesi, öteki dünya mutluluğunu elde edebilme adına bu dünyayı düzenlemekten ibarettir. Oysa veliliğin bu dünyayla bir ilgisi ve ilişkisi olmayıp, tanrısal bir konumu vardır. Sufi teoloji nübüvveti ve risaleti arızi, velayeti ise asli bir durum olarak görür. Zira peygamberlik ve elçilik izafe edildikleri şahıslara süreli olarak verilir, bu görevler onlarda baki olarak kalmaz. Oysa velilik, bu makama ulaşan bir kimsede sonsuza kadar devam eder. İbn Arabi, peygamberlik ve elçilik misyonu sona eren kimselerin genel velilik konumuna geçtiklerini ve öteki dünyada da bu konumlarını muhafaza ettiklerini savunur. ${ }^{64}$

Kur'an'ın, Allah'a itaat ile peygambere itaati özdeşleştiren ifadeleri, sufilerin peygamberlik algısına önemli ölçüde yön vermiştir. Bu durum onlar1, peygambere, "Beni gören Allah'ı görmüş demektir." ifadesini söyletecek noktaya getirmiştir. Sufi literatürde söz konusu edilen "mutaa" kavramı, Allah'ın halifesi ya da vekili, tüm evrenin Allah adına denetleyicisi olması nedeniyle kendisine itaat edilen kişi demektir. ${ }^{65}$ Bu bağlamda sufiler Tanrı ile mutaa arasındaki ilişkiyi ışık ile güneş ya da ateş ile kor arasındaki ilişkiye benzetmişlerdir. Bu kurgusal ilşki, Tanrı'nın nurundan bir nur olan Muhammedi nur teorisini gündeme getirir. Bu noktada beşeri düzlemde itaat edilen kişiyle Muhammedi nurun aynileşmesi söz konusudur. İtaat edilen kişi Muhammedi nur olarak, Tanrı adına aktif biçimde iş gören bir tanrısal yetkeye dönüşür. Tanrı'ya vekalet eden ve Onun adına iş gören bir yetkenin varlığı, Tanrı'nın işlevsiz kalması anlamına gelir. ${ }^{66}$

Tanrı-insan ilişkisinde sufi önderler kendilerini Peygamberin hakiki varisleri olarak; Onun ideal toplumunu yeniden oluşturma ve devam ettirme ad1na peygamberlik bilincinin mirasçıları olarak görmüşlerdir. Onlara göre bir kimsenin Peygamberin varisine ihtiyaç duymaması, peygambere ihtiyaç duymaması anlamına gelir. Başka bir ifadeyle varise ihtiyaç duymama, peygambere ihtiyaç duymamayı gerektirir. Zira Peygamber Kur'an'ı insanlara açılkla-

64 İbn Arabi, Fusus, 171 vd.; Kaşani, Şerhu Fusus, s.252-255.

65 Gazali, Mişkatu'l Envar, nşr. A. İzzet el-Mısri, Mısır, 1322, s.55.

66 Deizmi andıran bu yaklaşımda Tanrı'nın evrenin yaratıcısı olduğu gerçeği değişmez. Ancak O, doğrudan evrenin yönetimine ve düzenlenmesine müdahale etmemektedir. Bu görev Onun emriyle felekleri ve göksel alemi hareket ettirecek birisine, yani mutaa'ya verilmiştir. Tanrı'ya vekalet eden ve Onun adına iş gören Mutaa, yaratılmış bir varlık olarak Tanrı ile özdeş değildir. Buna karşılık Tanrı'nın suretinden yaratılmış olan ve kendinde ilahi güç taşıyan bu göksel insan, Muhammed'in arketipsel ruhunu temsil eder. Bu özelliğiyle o, evrenin düzeninin ve bekasının bağlı olduğu Külli Kudret olarak kabul edilir. Bkz. Nicholson, The Idea of Personality, s.61. 
sin diye gönderilmiştir. Bu konudaki veraset vekaleti ifade eder. ${ }^{67}$ Oysa Kelami teolojide peygamberliğe ait olan ile peygamberliğin dışında olan arasında kesin olarak ontolojik bir ayırım vardır. Buna bağlı olarak peygamberlik ve bununla ilgili her türlü görev Hz. Muhammed ile son bulmuştur.

Sufi teoloji peygamberin örnekliğini dahili ve harici olmak üzere ikiye ayırmaktadır. Yol göstericilik ya da irşad peygamberliğin içsel modelini, peygamberin fiillerinin taklidi ise onun dışsal modelini oluşturmaktadır. Başka bir ifadeyle içsel örneklik veliliğe, dışsal örneklik ise tarihsel elçiliğe karşlık gelmektedir. ${ }^{68} \mathrm{Bu}$ ayırımdan hareketle sufi önderlerin peygamberle benzer ya da aynı aracı fonksiyonlarının olduğu varsayılır. Veli ya da şeyh tıpkı peygamberde olduğu gibi yaratan ile yaratılan varlık arasında bir aracı yani berzah görevi görür. Peygamberin varisi ve peygamberlik eşiğine en yakın otorite olarak veli, aktüel Muhammed konumundadır. Hz. Muhammed'in ardından peygamberlik görevi, ruhsal bir bağla(veli) devam eder. Bunun da ötesinde peygamberliğin en temel özelliklerinden olan yol göstericilik ve irşad terimi sufi teolojide sadece ruhsal tecrübeleri değil aynı zamanda günlük yaşama ilişkin tecrübeleri de kapsar. Sufi önder bu noktada Tanrı ile insan arasında bir aracı vazifesi görerek nebevi uyarılara devam eder. Böylece insanlar, bu yol göstericilik ve irşad sayesinde Tanrı'ya daha yakın olurlar. Başka bir ifadeyle veli aracılığıyla insanların Peygambere ihtiyacı giderilir.

Sufi teolojide velinin ve velilik makamının nitelikleri dikkate alındığında, onun peygambere ve peygamberliğe göre kurgulandığı açıkça görülür. Bu gelenekte peygamberin işlevlerinin ve özelliklerinin veliye devredildiğini görmek gerekir. Sufilere göre veli, feyz ve ilhama mazhar olan, keramet ve istikamet sahibi bir kimsedir. Onun okuma ve yazma bilmesi şart değildir. Okuma ve yazması olmayan bir çoban bile veli olabilir. Çalışıp çabalayarak veli olunmaz ancak çalışıp çaba gösterenler arasından veliler çıkabilir. Velilik tümüyle Tanrı'nın hür iradesiyle yaptı̆̆ ve ihsandır. Tanrı dilediği kimseyi veli olarak seçer ya da seçmez. Bu yönüyle velilik, Tanrı'nın bir lutfu, fazlı ve hibesidir. ${ }^{69}$ Kuşeyri veliyi, etken ve edilgen bir kişilik olarak tasvir eder. Ona göre veli, bir yönüyle Tanrı'nın, işini üzerine aldığı ve kendisini kayırdığı bir kimse, diğer yönüyle Tanrı'ya ibadet ve taat işini üstlenen kimsedir. ${ }^{70}$

67 İbn Haldun, Tasavvufun Mahiyeti, haz. Süleyman Uludă̆, İstanbul, 1977, s.212.

68 Kaşani, Şerhu Fusus, s.55-56.

69 İbn Haldun, Tasavvufun Mahiyeti, s.230-231.

70 Kuşeyri, Kuşeyri Risalesi, s.426. 


\section{Mucize-Keramet}

Sufi teolojinin peygamberlik algısının önemli bir parçasını da keramet kavramı oluşturmaktadır. Sufi teorisyenlerin keramet kavramı bağlamında ürettikleri literatüre bakıldığında, bunun peygamberliğin ayırt edici özelliklerinden biri olan mucizeye paralel ve adeta ona alternatif oluşturacak bir tarzda kurgulandığını söylemek mümkündür. Sufi tecrübeyi ve bu tecrübenin en üst makamlarından biri olan veliliği peygamberlikle ilişkilendiren Gazali, velilerin gerek dişsal gerekse içsel olsun bütün hareket ve durgunluklarının peygamberlik kandilinin ışığından alındığını belirtir. Ona göre bu yolun bağlıları çeşitli aşamalarda peygamberlerin ruhlarını görür ve onlarla konuşurlar. Bu tür hayalleri gören kimseler, çeşitli mertebelere yükselirler, bunu sözle anlatma olanağ 1 yoktur. Velilerin yaşadığ nin peygamberlik hakikatine karşıllk geldiğini ifade eden Gazali, akıl yoluyla elde edilen veri ile zevk yoluyla ulaşılan veriyi birbirinden ayırarak, peygamberi hakikatin akıl ile değil zevkle kavranabileceğini düşünür. Gazali'ye göre bir hali akli kanıtlarla araştırmak ilim, o halin bizzat yaşanması ise zevktir. Zevke dayalı olmayan herhangi bir eylem peygamberlik hakikatini içermez. Buradan hareketle Gazali, velilerde ortaya çıkan kerametlerin, peygamberliğin ilk aşamasında görülen haller olduğunu ileri sürer. ${ }^{71}$ Sufi tecrübe ile peygamberlik arasında kurulan bu paralellik, peygamberlik ve mucizenin işlevinin velilik ve keramet aracılığıyla devam ettiği sonucunu kaçınılmaz olarak doğurmaktadır.

Dinsel bir gerçekliği vurgulamak, inananları desteklemek, iyi kimselere yardım etmek, inançsızları cezalandırmak amacıyla ilahi gücün ve iradenin evrene özel bir tarzda müdahale ettiği düşüncesine pek çok dinsel gelenekte özel bir önem atfedilir. Müslüman geleneğinde ise Tanrı'nın bu müdahalesi mucize ${ }^{72}$ olarak adlandirılır. Mucize, Adetullah/Sunnetullah denilen tabiat kanunlarını geçici olarak durduran veya askıya alan, insanları benzerini gerçekleştirmekten aciz bırakan, peygamberin elinde meydana gelen Tanrı'nın peygamber olarak seçtiği kimseyi doğrulamak ve desteklemek için yarattığı olağanüstü olay ya da fiildir.

Mucizede insanları aciz bırakan Tanrı'nın kendisidir. "Peygamberin mucizesi" ifadesinde mucizenin peygamberlere atfedilmesi mecazendir.

71 Gazali, el-Munkız, s.62-63.

72 Kur'an'da, "mucize" kelimesi terim anlamıyla yer almayıp, peygamberlerin Tanrı'nın elçileri olduğunu kanitlayan olağanüstü olaylar, âyet ya da âyât(7 A'raf,73, 106-108; 11 Hud, 96; 28 Kasas,31-32,35), beyyine(7 A'raf,73), burhân, sultân(28 Kasas,32; 4 Nisa,153; 11 Hud,96), hak(10 Yunus,76) ve furkân(2 Bakara,53) gibi kelimelerle ifade edilir. 
Tanrı'nın bir fiili olan mucize, peygamberin peygamberliğini doğrular ve destekler. Zira peygamberlerin peygamberliklerini doğrulayacak ve onların Tanrı tarafından gönderildiğini ortaya koyacak mucizelere ihtiyacı vardır. Peygamberlere mucize verilmesinin en önemli nedenlerinden biri de insanlara, akıllarını kullanarak tabiat kanunlarına aykırı olarak gerçekleşen bir olayın ancak Tanrı tarafından yapılacağını öğretmektir. Bir peygambere verilen mucize diğer peygambere verilmemiştir. Her peygamberin mucizesinin diğerlerininkinden farklı olması, mucize olgusunun doğasının gereğidir. Zira tekerrür eden olay, olağanüstü olmaktan çıkarak olağan hale gelir. Olağan fiiller ya da olaylar ise mucize olarak değerlendirilemez. Müslüman geleneğinde peygamber dişında herhangi bir kimsenin gösterdiğ̈i, olağanüstü varsayılan hiçbir olay mucize olarak değerlendirilemez. ${ }^{73}$

Mucizeler, idrak edilmeleri açısından, hissî, haberî ve aklî olmak üzere üçe ayrilır. Duyular yoluyla idrak edilen olağanüstü olaylar hissi, peygamberlerin vahye dayanarak gelecekte gerçekleşecek olaylar hakkında bilgi vermelerine haberî, insanların akıl yürütme yeteneğine hitap eden, onları akli kanıtlarla baş başa bırakan, düşünmekle kavranabilen, evrensel özellik taş1yan gerçeklere de aklî mucize denir. Kur'an'ın Hz. Muhammed'e verilen aklî bir mucize olduğu konusunda Müslüman bilginler görüş birliği içindedir. Ancak Hz. Muhammed'e, ayın yarılması, İsra ve Miraç, Bedir savaşında meleklerin Müslümanlara yardım etmesi, az yemekle birçok insanı doyurmak gibi hissî mucizelerin de verildiği ileri sürülmektedir. Ancak Kur'an'da, inkârcıların Hz. Muhammed'den hissî mucize isteğine karşı, onun insanî niteliklerine, sadece tebliğle görevli olduğuna, inanma isteğinde bulunmayanlara bu tür olayların yarar sağlamayacağına, akıl ve sağduyu sahibi kimselere mucize olarak Kur'an'ın yeterli olacağına dikkat çekilmektedir. ${ }^{74}$

Sufi teolojide keramet, tıpkı mucize gibi tabiat kanunlarıyla açıklanamayan olağanüstü ve sıra dişı olay ve fiil olarak kabul edilerek, her iki olayın aynı mahiyette olduğu ve aynı kaynaktan geldiği düşünülür. Sufi teorisyenler kerameti, Allah'ın veli kullarından ortaya çıkan olağanüstü olay ve fiil ${ }^{75}$ şeklinde tanımlamışlardır. Sufi teorisyenlerin kerameti adeta mucizeye alternatif bir tarzda kurgulamaları, aklı ve metni referans alan teologların, söz konusu kurgunun dinin peygamberlik tasavvuruna açık bir tecavüz ve tahrif oluşturduğu gerekçesiyle, eleştirilerine neden olmuştur. Sufi teorisyenler bu kaygıları giderme adına, mucize ile keramet arasındaki

73 Akbulut, Ahmet, Nübüvvet Meselesi Üzerine, Ankara, 1992, s.16-38.

74 bkz. 6 En'am,35; 21 Enbiya,5-6; 13 Ra'd,7; 26 Şuara,3-5; 28 Kasas,48-49; 17 İsra,59; 29 Ankebut, 47-51

75 Kuşeyri, Kuşeyri Risalesi, s.530 vd.; Kelabazi, Taaruf, s.106 vd. 
farkı bütün incelikleriyle belirtmek için özel teoriler geliştirmişler ve bu teoriler aracılı̆̆ıyla mucize ve keramet arasında bir rekabet ve çatışmanın olmadığını göstermeye çalışmışlardır. ${ }^{76}$ Sufi teolojinin velilik tasavvuru düşünüldügüünde, sufi teorisyenlerin bu çabasının bir anlamı kalmamaktadır. Bütün sıfatları ve zatıyla Tanrı'da yok olarak, yani bütün beşeri niteliklerini Tanrı'da yitirerek Onun bilincine ortak olan velinin, sıra dışı bir kudrete sahip olmasından, idrakinin olağanüstü bir faaliyet yürütmesinden daha doğal ne olabilir ki? Zira velilik makamına ulaşan bir kimse bütün varlığı ve fiilleriyle ilahi boyut taşır.

İhsan, ikram, cömertlik, şeref, bă̆ış ve lütuf gibi anlamlara gelen keramet kelimesi, Övgüye layık nitelikleri taşıyan, varlıklara çokça lütuf ve ihsanda bulunan, ikram sahibi cömert varlık anlamında Tanrı'nın adlarından biri olan kerim kelimesi ile aynı kelime kökünden türemiştir. Sufi teoloji nasıl ki Tanrı'ya ait olan veli ismini, belirli bir makama ulaşan kimse için kullanmayı uygun bulduysa, kerametin de ancak kamil insan modeli olan veliye uygun düşeceğini kurgulamıştır. Mucizede Tanrı'nın peygamber aracllı̆̆ıyla evrene bir müdahalesi söz konusu iken, keramet de herhangi bir vasıta söz konusu değildir. Burada ilahi bilince ortak olan velinin kişisel gücünün doğrudan ortaya çıkması gündemdedir. Keramet türü olaylarda ilahi müdahale bizzat devrededir. Aslında velinin bu faaliyeti bir tür yaratma eylemidir. ${ }^{77} \mathrm{Bu}$ yaratma eyleminde gizlilik esas olup, ideal insan modeli bunu gerekli kilmaktadır.

Tasavvuf geleneğinde olduğu gibi hemen her mistik gelenekte veli, aziz gibi belirli kişilere ruhsal güçler atfetme ya da bu kişilerde alışılmışın dışında bazı güçler vehmetme düşüncesi hep var olagelmiştir. Ancak başlangıç dönemi sufi temsilciler keramet olarak adlandırılan olayların abartılmaması gerektiğini, hatta bu tür fiil ve olayların aldatıcı, tehlikeli ve zararlı olduğunu düşünmüşlerdir. Bu sufi otoriteler, gerçek kerametin, Tanrı'nın buy-

76 Sufi teorisyenler her iki olağanüstü ve sıra dışı olay türünün de esas itibariyle aynı olduğunu, aynı kaynaktan geldiğini itiraf etmekle birlikte, her birinin sahip olduğu özellikleri ayırt etmek için çaba harcamışlardır. Onlara göre mucize, peygamberlerin doğruluğuna ve peygamberlik görevinin ispatına yönelik olağanüstü bir olay iken keramet, veliliğin ispatına yönelik değildir. Ayrıca mucize olayında gizleme değil, özellikle açıklama ve muhataplara meydan okuma söz konusudur. Keramette ise esas olan gizlemedir. Bu tür olaylarda herhangi bir iddia ve meydan okuma gerçekleşmez. Bkz. Kuşeyri, a.g.e., s.530 vd.; Kelabazi, Taaruf, s.106-116.

77 İbn Arabi'ye göre sıradan her insan var olmayan bir şeyi zihinsel olarak üretme imkanına sahiptir. Bizler zihnimizde var olmayan şeyleri tasavvur edebiliriz. Böylece hayali olarak tasavvur ettiğimiz bir şey ancak zihinle sınırlıdır. Ancak velilik makamına ulașmıș ve tanrısal bilince bürünmüş olan arifler, dış dünyada var olmayan bir şeyi var kılabilme niteliğine sahiptirler. Ona göre bu durum bir tür yaratmadır, ancak Tanrı’nın yaratışından farklıdır. Bkz. İbn Arabi, Fusus, 88-89. 
ruklarına özenle uyma, kötü alışkanlıkları ve davranışları terk edip ahlaki tutarlılık gösterme, benliği eğitme, bilgilenme yolunda çaba harcayarak olgun bir insan olma olduğunu ifade etmişlerdir. Ancak başlangıç dönemi sufiliğinin bu ahlaki ideali yerini velâyetnamelere ve velilik kültüne bırakmıştır. Keramete dayalı efsane ve hikâyeler sufiliğin belirleyici teması haline gelmiştir. Özellikle Hz. Muhammed'in şahsında tabiatüstü hiçbir şey barındırmadığı ve Onun diğer insanlardan hiçbir farkının bulunmadığı yönündeki Kur'ani uyarılar bir tarafa itilerek, kendisinin de hiçbir şekilde tasvip etmeyeceği efsane ve mitolojilerle çevrili insanüstü bir kişiliğe büründürülmüştür. Başta Hz. Muhammed olmak üzere önde gelen sufi temsilcileri hakkındaki romantik menkıbe literatürü masallarda sık sık karşılaştığımız insanüstü karakterlerle dolup taşmıştır.

Velilik ve kerametleri kapsamında söz konusu edilen su üzerinde yürüme, havada uçma, yağmur yağdırma, aynı anda birkaç yerde görünme, nefesle tedavi, ölüleri diriltme, gelecek olayları önceden bilme ve kehanet, düşünceleri okuma, olayları kontrol altına alma, muhatabı söz ve işaretle felç etme, hayvan ve bitkilerle konuşma, yiyecek ve içecek temin etme gibi konuları işleyen hiçbir akli, ahlaki ve teklifi kaygı taşımayan hikâyeler, dinin ve dindarlığın tezahürü olarak görülmüştür. Kendisinde ilahi bir bilinç ve kudret vehmeden velinin, artık zaman, mekan ve tabiat kurallarından herhangi birisinin kendisini sınırladığını düşünmesi mümkün müdür? Dolayısıyla onun, göz açıp kapatıncaya kadar bir mekandan diğerine, bir zamandan ötekine intikal etmesinden daha doğal ne olabilir ki? İlahi bilinç ve kudretle sarıp sarmalanmış velide, zamansal ve mekansal mesafeler anlamını yitirir. Velinin tabiatüstü bilinç ve kudreti, sadece zaman ve mekanı aşmayla sınırlı kalmaz. Bu kudret, var olmayanı varlığa çıkarmak, eşyanın mahiyetine nüfuz ederek değiştirmek, tabiat olaylarına müdahale edip istediği gibi yönlendirmek gibi işlevler görür.

Sufi teorisyenler kerametleri dinsel bir içerikle kullanarak dinin ötesindeki gerçekliğe, yani görünenin ötesindeki görünmeyene ulaşmaya çalışırlar. Onlardaki zahir batın ayırımı Tanrı, evren ve insanla ilgili her şeyde geçerlidir. Beşeri düzlemde ve görünen alemde gerçekleşen kerametler, görünmeyen alemin bilgisine ve gerçekliğine ulaşmanın vasıtalarıdır. Onlara göre hakikate, ne dinle, ne bilimle ne de akli faaliyetlerle ulaşılabilir. Dini, felsefi ve bilimsel olan hakikat değildir. Hakikat olan Tanrı'ya, evrene ve insana gizemli ve sihirsel bakıştır. Onların bu bakışı ile mitolojilerin bakışı arasında fark yoktur. ${ }^{78}$ Şu halde sufiliğin peygamberlik algısı dinsel olmak-

78 Cabiri, Muhammed Abid, Arap-İslam Kültürünün Akıl Yapısı, İstanbul, 1999, s.479. 
tan çok mitolojiktir. Sufi teolojinin hayal gücüne dayalı bu mitolojik karakteri, peygamberliği beşeriyet tarihinin de ötesine taşır. Bu noktada her ne kadar peygamberin ilahlığı iddia edilmese de, kendisinde ilahi bir güç ve bilinç taşıması nedeniyle o, ilahtan bir parça taşıyan varlıktır.

\section{Sonuç}

İslam'ın insanlığa önerdiği en temel ilkelerden biri, ilahi adalet önünde ilahi buyruklara karşı maksimum özen göstermeye dayalı ahlaki sorumluluktur. Hangi düzeyde olursa olsun hiçbir ayrıcalık içermeyen bu ahlaki sorumluluk, bir yandan yaratılışta insan türünün doğasına yerleştirilen akla ve özgürlüğe diğer yandan Tanrı'nın uyarması ve hatırlatmasına yani peygamberliğe dayanır. Bu bağlamda peygamberlik söz konusu ahlaki sorumluluğu hatırlatmaya ve gündemde tutmaya yönelik beşeri bir faaliyettir. Kur'an, peygamberlik konusunda birbiriyle ilişkili olmak üzere, vahiy almak ve beşer olmak şeklinde iki temel nitelik belirlemiştir. İslam düşüncesi kapsamında yürütülen herhangi bir teolojik faaliyet, peygamber ve peygamberlikle ilgili bu iki esası dikkate almak durumundadır. Bu iki esası göz ardı ederek ya da iyi niyetle de olsa herhangi bir biçimde tahrif ederek yapılan her türlü teolojik spekülasyonun meşruiyetinin olması mümkün değildir.

Tanrı'nın insanlar arasından seçtiği peygamberlerin ve peygamberlik görevinin varoluş nedenlerinden biri belki de en önemlisi Tanrı ile bireysel düzlemde insan arasındaki ilişkiyi düzenlemeye yöneliktir. Peygamberlik aracılığı ile gerçekleştirilen bu düzenlemenin nihai amaçlarından biri, her türlü ortaklıktan ve benzerlikten arınmış saf bir Tanrı anlayışı oluşturmaktır. Bunun yanında ilahi bir lütuf ve yardım olarak peygamberlik aynı zamanda, Tanrı ile birey ve bireylerarası ilişkinin ahlaki bir temele oturtulmasını sağlamaya yöneliktir. Her türlü ortaklık ve benzerlikten uzak Tanrı'yı birlemeye dayalı inanç ve insan doğasına uygun belli bir ahlaki standardizasyon bir din olarak İslam'ı diğer dinlerden ve öğretilerden ayıran ve onun özgünlüğünü ifade eden iki temel ilke olarak peygamberliğe varlık nedenini vermektedir.

Kur'an'ın oldukça yalın bir biçimde sınırlarını belirlediği peygamberlik konusu, Müslüman geleneğince, başta Hıristiyanlık ve Yahudilik olmak üzere pek çok dinsel ve felsefi kaynaktan yapılan alıntı ya da etkilerle mitolojik ve felsefi öğelerle çepeçevrelenmiştir. İslam düşüncesi içerisinde bu durumun en üst düzeyde yaşandığı alanın sufi tecrübe olduğunu söylemek mümkündür. Örneğin Kur'an, Hz. Muhammed'in Kur'an dışında hiçbir mucize göstermediğini söylemesine rağmen, sufi teoloji adeta diğer dinsel ve 
felsefi öğretilerle yarışır biçimde onu özellikle insanların hislerine hitap eden mucize, keramet ve efsanevi olaylarla sarmalanmış bir kişiliğe büründürmüştür. Bu durum öyle noktalara vardırılmıştır ki bazen o, realiteden uzak ezeli ve ebedi tanrısal bir 1şık, bazen gelecekten haber veren kâhin, bazen de tarih ve mekan üstü metafiziksel kaynak biçiminde tasavvur edilmiștir.

Kur'an'ın peygamberlik kapsamında söz konusu ettiği insanlara sorumluluk yükleyen vahiy, sufi paradigmada kapsamı genişletilerek subjektif karakterli ilhama; uyarma ve müjdelemeyle sınırlı elçilik, Tanrı adına iş gören ve ona vekalet eden, kendisinde tanrısal bir bilinç taşıdığı varsayılan veliliğe; Tanrı'nın bir fiili olan ve ancak peygamberlik görevi ile sınırlı olan olağanüstü olaylar, sihirsel ve büyüsel motiflerle örülü kerametlere dönüşmüştür. Genelde bir bütün olarak Müslüman geleneğin özelde ise sufi teolojinin peygamberi, Kur'an'ın özellikle altını çizdiği insan olma vasfını yitirerek, insanüstü niteliklere sahip metafiziksel bir varlığa, efsane ve mitolojilerde sık sık karşılaşılan hayali bir karaktere dönüşmüştür.

Sufi peygamberin menkıbelerle örülü dünyası, akla, bilime, dine ve insanın doğasına uymayan unsurlar içermektedir. Söz konusu peygamberlik anlayışı dinsel olmaktan çok sihirsel ve mitolojik bir karakter taşır. Bir din olarak İslam'ı diğer teistik dinlerden ve her türlü felsefi öğretiden ayıran ve ayrıcalıklı kılan en temel konuların başında gelen peygamberlik, iyi niyetli girişimlerle de olsa içerik ve imaj dönüşümü yaşayarak gerçek anlamını yitirmiş durumdadır. Kur'an'ın, Müslümanların eliyle yitirilmiş, özgün peygamberini keşfedip insanlığa yeniden sunmak Tanrı'nın her Müslüman bireye yüklediği tarihsel bir sorumluluktur. 